\title{
Detection and characterization of bacterial endosymbionts in Southeast Asian tephritid fruit fly populations
}

Elias D. Asimakis ${ }^{1}$, Vangelis Doudoumis ${ }^{1,2}$, Ashok B. Hadapad ${ }^{3}$, Ramesh S. Hire ${ }^{3}$, Costas Batargias², Changying Niư ${ }^{4}$ Mahfuza Khan ${ }^{5}$, Kostas Bourtzis ${ }^{6}$ and George Tsiamis ${ }^{1 *}$

\begin{abstract}
Background: Various endosymbiotic bacteria, including Wolbachia of the Alphaproteobacteria, infect a wide range of insects and are capable of inducing reproductive abnormalities to their hosts such as cytoplasmic incompatibility $(\mathrm{Cl})$, parthenogenesis, feminization and male-killing. These extended phenotypes can be potentially exploited in enhancing environmentally friendly methods, such as the sterile insect technique (SIT), for controlling natural populations of agricultural pests. The goal of the present study is to investigate the presence of Wolbachia, Spiroplasma, Arsenophonus and Cardinium among Bactrocera, Dacus and Zeugodacus flies of Southeast Asian populations, and to genotype any detected Wolbachia strains.
\end{abstract}

Results: A specific 165 rRNA PCR assay was used to investigate the presence of reproductive parasites in natural populations of nine different tephritid species originating from three Asian countries, Bangladesh, China and India. Wolbachia infections were identified in Bactrocera dorsalis, B. correcta, B. scutellaris and B. zonata, with 12.2-42.9\% occurrence, Entomoplasmatales in B. dorsalis, B. correcta, B. scutellaris, B. zonata, Zeugodacus cucurbitae and Z. tau (0.8-14.3\%) and Cardinium in B. dorsalis and Z. tau (0.9-5.8\%), while none of the species tested, harbored infections with Arsenophonus. Infected populations showed a medium (between 10 and 90\%) or low (<10\%) prevalence, ranging from 3 to 80\% for Wolbachia, 2 to 33\% for Entomoplasmatales and 5 to $45 \%$ for Cardinium. Wolbachia and Entomoplasmatales infections were found both in tropical and subtropical populations, the former mostly in India and the latter in various regions of India and Bangladesh. Cardinium infections were identified in both countries but only in subtropical populations. Phylogenetic analysis revealed the presence of Wolbachia with some strains belonging either to supergroup B or supergroup A. Sequence analysis revealed deletions of variable length and nucleotide variation in three Wolbachia genes. Spiroplasma strains were characterized as citri-chrysopicola-mirum and ixodetis strains while the remaining Entomoplasmatales to the Mycoides-Entomoplasmataceae clade. Cardinium strains were characterized as group A, similar to strains infecting Encarsia pergandiella.

Conclusions: Our results indicated that in the Southeast natural populations examined, supergroup A Wolbachia strain infections were the most common, followed by Entomoplasmatales and Cardinium. In terms of diversity, most strains of each bacterial genus detected clustered in a common group. Interestingly, the deletions detected in three Wolbachia genes were either new or similar to those of previously identified pseudogenes that were integrated in the host genome indicating putative horizontal gene transfer events in B. dorsalis, B. correcta and B. zonata.

Keywords: 165 rRNA, Multi locus sequence typing, Wolbachia, Arsenophonus, Cardinium, Spiroplasma, Horizontal gene transfer, Bactrocera, Zeugodacus

\footnotetext{
* Correspondence: gtsiamis@upatras.gr

${ }^{1}$ Department of Environmental Engineering, University of Patras, 2 Seferi St.,

30100 Agrinio, Greece

Full list of author information is available at the end of the article
} 


\section{Background}

In recent years, many maternally inherited endosymbiotic bacteria, capable of manipulating the reproductive functions of their hosts, have been identified in a wide range of arthropod species [1]. Among them, the most thoroughly studied are those that belong to the genus Wolbachia, a highly diverse group of intracellular endosymbionts belonging to the Alphaproteobacteria [2-4]. Wolbachia infections are widespread in insect species with estimates suggesting an incidence rate ranging from 20 to $66 \%$ [5-10]. Wolbachia infections vary significantly between species and also between different geographical populations of a species, exhibiting either high $(>90 \%)$ or low prevalence $(<10 \%)[5,11,12]$. Overall, the diverse interactions of Wolbachia with their hosts cover a broad spectrum of biological, ecological and evolutionary processes [13-17]. One of the most interesting aspects of Wolbachia interactions is the induction of a range of reproductive abnormalities to their hosts, such as cytoplasmic incompatibility (CI), parthenogenesis, male-killing and feminization of genetic males so they develop as females [3, 14, 18-20]. For instance, in woodlice, genetic males develop as females when Wolbachia disrupts a gland that produces a hormone required for male development [21]. In this way, the bacteria change the birth ratio in favor of females, ensuring their steady proliferation within host populations, since they are vertically transmitted by infected females [2, 3, 17, 20, 22].

Apart from Wolbachia, additional reproductive symbionts from distantly related bacterial genera have been recently brought to light, such as Arsenophonus, Cardinium and Spiroplasma. Strains belonging to the genus Cardinium, a member of the phylum CytophagaFlavobacterium-Bacteroides (CFB), exhibit the same broad range of reproductive alterations with Wolbachia [23-29], with the exception of male-killing which has not been identified yet $[1,17,28]$. On the other hand, members of Arsenophonus, of the Gammaproteobacteria, and Spiroplasma, wall-less bacteria belonging to the class Mollicutes, are known to induce male-killing phenotypes [1, 17, 30-32]. The incidence rate of all three genera in insects was shown to vary between 4 and $14 \%$, fairly lower than that of Wolbachia [1, 33-39], although higher occurrence was observed for Arsenophonus in aphids and ants, reaching up to 30 and $37.5 \%$ of species respectively $[40,41]$ as well as for Cardinium in planthoppers (47.4\% of species) [36]. In Cardinium and Spiroplasma-infected species a wide range of prevalence (15-85\%) was observed while in the case of Arsenophonus, prevalence reached values above $75 \%$ with relatively few exceptions, such as the wasp Nasonia vitripennis with a $4 \%$ infection rate or various ant species that showed a broader range (14-66\%) [1, 38, 40, 42].
Insect species belonging to the genus Bactrocera and the closely related species Dacus longicornis (Wiedemann), Z. cucurbitae (Coquillett) and Z. tau (Walker) are members of the Tephritidae, a family of fruit flies with worldwide distribution that contains important agricultural pests, capable of affecting a variety of fruit and horticultural hosts [43-46]. The direct damage to hosts caused by female oviposition and the development of the larvae, results in severe losses in fruit and vegetable production. Their economic impact also expands to trade, with strict quarantine measures imposed on shipments originating from infested countries [47-50]. The reproductive alterations induced by the bacterial symbionts, as well as their role in insect host biology and ecology, could be used in environmentfriendly approaches, such as the sterile insect technique (SIT) and other related techniques, for the area-wide integrated pest management (AW-IPM) of insect pest populations [13, 51-65].

The current classification of Wolbachia strains based on molecular markers includes 16 supergroups, from A to $Q$, with the exception of $G$ which has been merged with $A$ and $B$ [66-71]. Classification is primarily based on the 16S rRNA gene but other commonly used genetic markers include the gltA (citrate synthase), groEL (heatshock protein 60), $\operatorname{cox} A$ (cytochrome c oxidase), $f b p A$ (fructose-bisphosphatealdolase), fts $Z$ (cell division protein), gatB (glutamyl-tRNA(Gln) amidotransferase, subunit B), hcpA (hypothetical conserved protein) and wsp genes (Wolbachia surface protein) [7, 72, 73]. Strain genotyping is performed by multi locus sequence typing (MLST) using five conserved genes ( $\operatorname{cox} A, f b p A, f t s Z$, gat $B$ and $h c p A$ ), the wsp gene and four hypervariable regions (HVRs) of the WSP protein [74]. Similarly, Spiroplasma strains are divided into three groups, the apis clade, the citri-chrysopicola-mirum clade and the ixodetis clade [75, 76]. Phylogenetic analyses are primarily based on the 16S rRNA gene, while more detailed MLST approaches include partial sequencing of the $23 \mathrm{~S} r R N A$, 5S rRNA, gyrB, rpoB, pgk (phosphoglycerate kinase) parE, fts $Z$, fruR genes, as well as the complete $16 \mathrm{~S}-23 \mathrm{~S}$ internal transcribed spacer region (ITS) [75, 77]. The remaining closely related Entomoplasmatales genera, Mycoplasma, Entomoplasma and Mesoplasma, form the separate Mycoides-Entomoplasmataceae clade [76]. Phylogenetic analyses for Cardinium are performed with the use of the 16S rRNA and gyrB genes but also with the amino acid sequence of Gyrase B ( $g y r B$ gene) [35, 36, 78-80]. Cardinium strains can be separated into group $\mathrm{A}$, which infect wasps, planthoppers, mites and other arthropods, group B, found in parasitic nematodes and group $C$ in biting midges [36].

Several studies reported that genes, chromosomal segments of various sizes or even the entire Wolbachia 
genome have been horizontally transferred to host chromosomes [81, 82]. The first incidence of a horizontal gene transfer (HGT) event was described in the adzuki bean beetle Callosobruchus chinensis (L.), where 30\% of the Wolbachia genome was found to be integrated in the $\mathrm{X}$ chromosome [83, 84]. Such events have also been described in a variety of insect and nematode hosts, including the fruit fly Drosophila ananassae and the tsetse fly Glossina morsitans morsitans [81, 85-89]. In G. m. morsitans two large Wolbachia genome segments of 527 and 484 Kbp have been integrated into the $\mathrm{Gmm}$ chromosomes, corresponding to $51.7 \%$ and $47.5 \%$ of the draft Wolbachia genome [90]. In the case of Drosophila ananassae, nearly the entire $\sim 1.4 \mathrm{Mbp}$ Wolbachia genome has been integrated in a host chromosome [81] while in Armadillidium vulgare the $\sim 1.5 \mathrm{Mbp}$ Wolbachia genome was not only integrated but also duplicated, resulting in the formation of a new female sex chromosome [91]. In the case of the mosquito Aedes aegypti, the direction of the HGT is not clear and could have happened either from the insect or from Wolbachia [92, 93]. Usually, the incorporated fragments lose their functionality and become pseudogenes with low levels of transcription [88]. However, some of these genes are highly expressed and can either provide a new function to the host, or replace a lost one [89, 92, 93]. These new functions may provide hosts with nutritional benefits, enable them to parasitize other eukaryotes, survive in unfavorable environments or protect themselves from other organisms [88].

In the present study, we investigate the presence of Wolbachia, Cardinium and Entomoplasmatales (the genera Spiroplasma, Entomoplasma and Mesoplasma) infections in natural populations of Bactrocera, Dacus and Zeugodacus fruit fly species. The detection and the phylogenetic analysis of the bacterial genera were based primarily on the use of the $16 \mathrm{~S} r R N A$ gene. Additionally, the molecular characterization of the Wolbachia strains was performed with the use of the wsp and MLST gene markers. Finally, we report on the presence of Wolbachia pseudogenes suggesting putative horizontal transfer events to the genome of various Bactrocera species and Z. cucurbitae.

\section{Results}

\section{Infection prevalence of reproductive symbiotic bacteria} Wolbachia, Entomoplasmatales and Cardinium infections were detected in 15 populations, divided into six species of Bactrocera and Zeugodacus (Tables 1, 2). Wolbachia was the most prevalent with 64 out of 801 (8\%) infected individuals, followed by 40 (5\%) Entomoplasmatales and 12 (1.5\%) Cardinium (Tables 1 and 2). On the contrary, no Arsenophonus infections were found in any of the populations tested. Bactrocera minax (Enderlein),
B. nigrofemoralis (White \& Tsuruta) and D. longicornis were the only species that did not harbor any infections of the bacterial symbionts tested in this study (Table 2).

The presence of Wolbachia, at variable infection rates, was identified in seven populations from four different species of tephritid fruit flies (Table 2). The most prevalent infections were observed in B. scutellaris (Bezzi) (42.9\%) and B. correcta (Bezzi) (30\%) compared to B. dorsalis (Hendel) (13.2\%) and B. zonata (Saunders) $(12.2 \%)$ (chi-squared test: $p$-values $<0.01)$. On the other hand, no Wolbachia infections were identified in the remaining species tested, namely, $D$. longicornis, $B$. minax, B. nigrofemoralis, Z. cucurbitae and Z. tau. Variation in prevalence was observed between field populations of the same species from different geographic regions. For example, Wolbachia infections in B. zonata were characterized by $80 \%$ prevalence in a population from Raichur, India, by $40 \%$ in Trombay, India and were absent from the remaining four areas tested (Table 1, Additional file 1). Heterogeneity in infection rates was also observed in $B$. dorsalis, which showed medium prevalence (46.7 and 66.7\%), except for a population from Rajshahi - the only infected population from Bangladesh - which showed a considerably lower infection rate $(2.8 \%)$ (chi-squared test: $p$-values $<0.01)$. The remaining four $B$. dorsalis populations appeared to be free of Wolbachia infections. Only one of two B. correcta populations studied was infected with Wolbachia, the population originating from the area of Trombay, India with $40 \%$ prevalence. Finally, in the case of $B$. scutellaris, the only population tested was found to be infected at $42.9 \%$ rate. Wolbachia prevalence also ranged significantly between populations of the same species that originated from different countries, with fruit flies from India exhibiting higher infection rate than those from Bangladesh. More specifically, Indian populations of $B$. dorsalis and $B$. zonata exhibited 53.3 and $40 \%$ prevalence respectively, significantly higher than populations from Bangladesh that were found to contain only $0.7 \%$ and pseudogenized Wolbachia sequences respectively (chi-squared test: $p$-values< 0.01) (Table 1).

The occurrence of Spiroplasma and its relative genera, Entomoplasma and Mesoplasma, displayed variation between different species, populations and countries (Tables 1, 2). Again, the most prevalent infections per species were observed in B. scutellaris (14.3\%) followed by B. dorsalis (9.6\%) and B. zonata (7.8\%). Three more species were infected with members of the Entomoplasmatales, including B. correcta (3.3\%), and at much lower rate compared to the three species with prevalent infections, Z. cucurbitae (2.4\%) and Z. tau $(0.9 \%)$ (chi-squared test: $p$-values $<0.01)$. The remaining species that were tested, including $B$. minax, $B$. 
Table 1 Prevalence of reproductive bacteria in tephritid fruit fly populations from Bangladesh, China and India using a 16S rRNA gene-based PCR screening approach. For each genus the absolute number and the percentage (in parentheses) of infected individuals are given. The last column on the right ("Total*") indicates the total occurrence of all three Entomoplasmatales genera

\begin{tabular}{|c|c|c|c|c|c|c|c|c|c|c|c|}
\hline & \multirow[b]{2}{*}{ Species } & \multirow[b]{2}{*}{ Country } & \multirow[b]{2}{*}{ State } & \multirow[b]{2}{*}{ Area } & \multirow[b]{2}{*}{ Samples } & \multirow[b]{2}{*}{ Wolbachia } & \multirow[b]{2}{*}{ Cardinium } & \multicolumn{4}{|c|}{ Entomoplasmatales } \\
\hline & & & & & & & & Spiroplasma & Entomoplasma & Mesoplasma & Total* $^{*}$ \\
\hline 1 & B. correcta & India & Maharashtra & Trombay & 25 & $10(40)$ & 0 & 0 & $1(4)$ & 0 & $1(4)$ \\
\hline 2 & B. correcta & India & Karnataka & Raichur & 5 & 0 & 0 & 0 & 0 & 0 & 0 \\
\hline 3 & B. dorsalis & Bangladesh & - & Rajshahi & 36 & $1(2.8)$ & 0 & 0 & $6(16.7)$ & 0 & $\begin{array}{l}6 \\
(16.7)\end{array}$ \\
\hline 4 & B. dorsalis & Bangladesh & - & - & 29 & 0 & 0 & 0 & 0 & 0 & 0 \\
\hline 5 & B. dorsalis & Bangladesh & - & Dinajpur & 22 & 0 & $10(45.5)$ & 0 & 0 & 0 & 0 \\
\hline 6 & B. dorsalis & Bangladesh & - & Dhaka & 34 & 0 & 0 & 0 & 0 & 0 & 0 \\
\hline 7 & B. dorsalis & Bangladesh & - & Jessore & 23 & 0 & 0 & 0 & 0 & 0 & 0 \\
\hline 8 & B. dorsalis & India & Maharashtra & Trombay & 30 & $14(46.7)$ & 0 & $2(6.7)$ & $5(16.7)$ & 0 & $\begin{array}{l}7 \\
(23.3)\end{array}$ \\
\hline 9 & B. dorsalis & India & $\begin{array}{l}\text { Himachal } \\
\text { Pradesh }\end{array}$ & Palampur & 15 & $10(66.7)$ & $1(6.7)$ & 0 & $5(33.3)$ & 0 & $\begin{array}{l}5 \\
(33.3)\end{array}$ \\
\hline 10 & B. minax & China & - & - & 40 & 0 & 0 & 0 & 0 & 0 & 0 \\
\hline 11 & $\begin{array}{l}\text { B. } \\
\text { nigrofemoralis }\end{array}$ & India & $\begin{array}{l}\text { Himachal } \\
\text { Pradesh }\end{array}$ & Palampur & 5 & $2^{a}(0)$ & 0 & 0 & 0 & 0 & 0 \\
\hline 12 & B. scutellaris & India & $\begin{array}{l}\text { Himachal } \\
\text { Pradesh }\end{array}$ & Palampur & 35 & $15(42.9)$ & 0 & 0 & $5(14.3)$ & 0 & $\begin{array}{l}5 \\
(14.3)\end{array}$ \\
\hline 13 & B. zonata & Bangladesh & - & Rajshahi & 21 & $2^{a}(0)$ & 0 & 0 & $2(9.5)$ & $2(9.5)$ & $4(19)$ \\
\hline 14 & B. zonata & Bangladesh & - & Jessore & 33 & 0 & 0 & 0 & 0 & 0 & 0 \\
\hline 15 & B. zonata & Bangladesh & - & Dinajpur & 26 & 0 & 0 & 0 & 0 & 0 & 0 \\
\hline 16 & B. zonata & India & Maharashtra & Trombay & 25 & $10(40)$ & 0 & 0 & $3(12)$ & 0 & $3(12)$ \\
\hline 17 & B. zonata & India & Karnataka & Raichur & 5 & $4(80)$ & 0 & 0 & 0 & $1(20)$ & $1(20)$ \\
\hline 18 & B. zonata & India & $\begin{array}{l}\text { Himachal } \\
\text { Pradesh }\end{array}$ & Palampur & 5 & 0 & 0 & 0 & $1(20)$ & 0 & $1(20)$ \\
\hline 19 & D. longicornis & Bangladesh & - & Dhaka & 21 & 0 & 0 & 0 & 0 & 0 & 0 \\
\hline 20 & Z. cucurbitae & Bangladesh & - & Rajshahi & 47 & 0 & 0 & 0 & 0 & 0 & 0 \\
\hline 21 & Z. cucurbitae & Bangladesh & - & Jessore & 55 & 0 & 0 & 0 & 0 & $1(1.8)$ & $1(1.8)$ \\
\hline 22 & Z. cucurbitae & Bangladesh & - & - & 30 & 0 & 0 & 0 & 0 & 0 & 0 \\
\hline 23 & Z. cucurbitae & Bangladesh & - & Dinajpur & 96 & $2^{\mathrm{a}}(0)$ & 0 & $1(1)$ & $2(2.1)$ & 0 & $3(3.1)$ \\
\hline 24 & Z. cucurbitae & Bangladesh & - & Dhaka & 29 & 0 & 0 & 0 & $2(6.9)$ & 0 & $2(6.9)$ \\
\hline 25 & Z. tau & Bangladesh & - & Jessore & 22 & 0 & 0 & 0 & 0 & 0 & 0 \\
\hline 26 & Z. tau & Bangladesh & - & Dhaka & 6 & 0 & 0 & 0 & 0 & 0 & 0 \\
\hline 27 & Z. tau & Bangladesh & - & Rajshahi & 31 & 0 & 0 & 0 & 0 & 0 & 0 \\
\hline 28 & Z. tau & Bangladesh & - & Dinajpur & 20 & 0 & $1(5)$ & 0 & 0 & 0 & 0 \\
\hline 29 & Z. tau & India & Maharashtra & Trombay & 10 & 0 & 0 & 0 & 0 & $1(10)$ & $1(10)$ \\
\hline 30 & Z. tau & India & $\begin{array}{l}\text { Himachal } \\
\text { Pradesh }\end{array}$ & Palampur & 20 & 0 & 0 & 0 & 0 & 0 & 0 \\
\hline Total & 9 & 3 & 3 & 7 & 801 & & & & & & \\
\hline
\end{tabular}

a. Only pseudogenised sequences

nigrofemoralis and D. longicornis, appeared to be free of Entomoplasmatales infections (Table 2). In some cases, the infection rate varied between different populations. For example, in $B$. dorsalis, prevalence ranged from $33.3 \%$ in Palampur, to $23.4 \%$ in the Trombay area, in
India and $16.7 \%$ in the Rajshahi District, in northwestern Bangladesh. There were also four populations from Bangladesh that did not contain any infections (Table 1). At the same time, B. zonata infection rates were almost uniform in three populations (19-20\%) 
Table 2 Prevalence of reproductive symbionts in different tephritid fruit fly species

\begin{tabular}{|c|c|c|c|c|c|c|c|c|}
\hline \multirow[b]{2}{*}{ Species } & \multirow[b]{2}{*}{ Country } & \multirow[b]{2}{*}{ Areas with infected populations } & \multirow[b]{2}{*}{ Samples } & \multirow[b]{2}{*}{ Wolbachia } & \multirow[b]{2}{*}{ Cardinium } & \multicolumn{2}{|c|}{ Entomoplasmatales } & \multirow[b]{2}{*}{ Mesoplasma } \\
\hline & & & & & & Spiroplasma & Entomoplasma & \\
\hline B. correcta & India & Trombay & 30 & $\begin{array}{l}10^{\mathrm{b}} \\
(30 \%)\end{array}$ & - & - & $\begin{array}{l}1 \\
(3.3 \%)\end{array}$ & - \\
\hline \multirow[t]{2}{*}{ B. dorsalis } & India & Trombay, Palampur & \multirow[t]{2}{*}{189} & \multirow{2}{*}{$\begin{array}{l}25^{\mathrm{b}} \\
(13.2 \%)\end{array}$} & \multirow{2}{*}{$\begin{array}{l}11 \\
(5.8 \%)\end{array}$} & \multirow{2}{*}{$\begin{array}{l}2 \\
(1.1 \%)\end{array}$} & \multirow{2}{*}{$\begin{array}{l}16 \\
(8.5 \%)\end{array}$} & \multirow[t]{2}{*}{ - } \\
\hline & Bangladesh & Rajshahi, Dinajpur & & & & & & \\
\hline B. minax & China & - & 40 & - & - & - & - & - \\
\hline B. nigrofemoralis & India & Palampur & 5 & $\begin{array}{l}2^{\mathrm{a}} \\
(0 \%)\end{array}$ & - & - & - & - \\
\hline B. scutellaris & India & Palampur & 35 & $\begin{array}{l}15 \\
(42.9 \%)\end{array}$ & - & - & $\begin{array}{l}5 \\
(14.3 \%)\end{array}$ & - \\
\hline \multirow[t]{2}{*}{ B. zonata } & India & $\begin{array}{l}\text { Trombay, Raichur, } \\
\text { Palampur }\end{array}$ & \multirow[t]{2}{*}{115} & $\begin{array}{l}14^{\mathrm{b}} \\
(12.2 \%)\end{array}$ & \multirow[t]{2}{*}{ - } & \multirow[t]{2}{*}{ - } & \multirow[t]{2}{*}{$\begin{array}{l}6 \\
(5.2 \%)\end{array}$} & \multirow[t]{2}{*}{$\begin{array}{l}3 \\
(2.6 \%)\end{array}$} \\
\hline & Bangladesh & Rajshahi & & $\begin{array}{l}2^{\mathrm{a}} \\
(0 \%)\end{array}$ & & & & \\
\hline D. longicornis & Bangladesh & Dhaka & 21 & - & - & - & - & - \\
\hline Z. cucurbitae & Bangladesh & $\begin{array}{l}\text { Dinajpur, Jessore, } \\
\text { Dhaka }\end{array}$ & 257 & $\begin{array}{l}2^{\mathrm{a}} \\
(0 \%)\end{array}$ & - & $\begin{array}{l}1 \\
(0.4 \%)\end{array}$ & $\begin{array}{l}4 \\
(1.6 \%)\end{array}$ & $\begin{array}{l}1 \\
(0.4 \%)\end{array}$ \\
\hline \multirow[t]{2}{*}{ Z. tau } & India & Trombay & \multirow[t]{2}{*}{109} & - & \multirow{2}{*}{$\begin{array}{l}1 \\
(0.9 \%)\end{array}$} & \multirow[t]{2}{*}{ - } & \multirow[t]{2}{*}{ - } & \multirow{2}{*}{$\begin{array}{l}1 \\
(0.9 \%)\end{array}$} \\
\hline & Bangladesh & Dinajpur & & & & & & \\
\hline
\end{tabular}

a. Only pseudogenized sequences

${ }^{\mathrm{b}}$. Both integral (genuine or full) and pseudogenized Wolbachia genes

and relatively lower in Trombay, India (12\%), while two populations were uninfected. The only population of B. scutellaris that was studied, carried Entomoplasmatales infections at medium rate $(14.3 \%)$ and populations of $B$. correcta, Z. cucurbitae, and $Z$. tau at even lower (1.8-10\%; Table 1). Spiroplasma infections were observed in only three individuals, two of them originating from a population of $B$. dorsalis from Trombay, in India and the third one from a population of $Z$. cucurbitae from Dinajpur, in northern Bangladesh (6.7 and 1\% respectively). The total prevalence in each species was 1.1 and $0.4 \%$ (Table 2). Differences in infection rates were also observed between different countries. In B. zonata for instance, $14.3 \%$ of samples from India were infected with Entomoplasmatales while in Bangladesh the infection rate was calculated at 5\% (Table 1).

Two populations of $B$. dorsalis and one of $Z$. tau were found to harbor Cardinium infections with much different prevalence. The most prevalent infection was identified in a population of $B$. dorsalis from Dinajpur, Bangladesh with $45.5 \%$ (Table 1) (chi-squared test: $p$ values $<0.01)$. A population of $Z$. tau, also from Dinajpur, carried a $5 \%$ infection, while the other infected $B$. dorsalis population originating from Palampur, India displayed a $6.7 \%$ infection rate. The prevalence of Cardinium infections was $5.8 \%$ in B. dorsalis and $0.9 \%$ in Z. tau (Table 2) (chi-squared test: $p$-values $<0.04$ ). Finally, in the case of $B$. dorsalis, populations from
Bangladesh showed higher prevalence, but without statistical significance, than those from India $(6.9 \%$ compared to $2.2 \%$ ).

\section{MLST genotyping for Wolbachia strains}

Sequence analysis revealed the presence of several alleles for all MLST, wsp and 16S rRNA loci: three for gatB, two for $\operatorname{cox} A$, two for $h c p A$, two for $f t s Z$, two for $f b p A$, two for $w s p$ and nine for the $16 \mathrm{~S} r R N A$. Interestingly, more than half of the MLST and wsp alleles were new in the Wolbachia MLST database: two for gatB, one for $\operatorname{cox} A$, one for $h c p A$, two for fts $Z$, one for $f b p A$ and one for $w s p$, respectively (Table 3 ). Cloning and sequencing of the MLST, wsp and 16S rRNA gene amplicons clearly indicated the presence of multiple strains within individuals of three populations (Table 3). In more detail, multiple bacterial strains with two potential Sequence Types (STs, combination of alleles) were detected in the infected B. zonata sample (2.2) from Trombay. The second infected B. zonata sample (8.2) contained four possible ST combinations. In addition to these multiple infections, we found double $16 \mathrm{~S} r R N A$ alleles in four Indian samples, in B. correcta $(1.4$ and $01.5 \mathrm{H})$ from Trombay, in B. scutellaris (02.5E) from Palampur and in B. zonata (01.4E) from Raichur.

\section{Phylogenetic analysis}

The Wolbachia phylogenetic analysis was carried out on seven Wolbachia-infected natural populations and was 
Table 3 Wolbachia MLST, wsp, 16S rRNA allele profiles and pseudogenes for infected Bactrocera and Z. cucurbitae populations

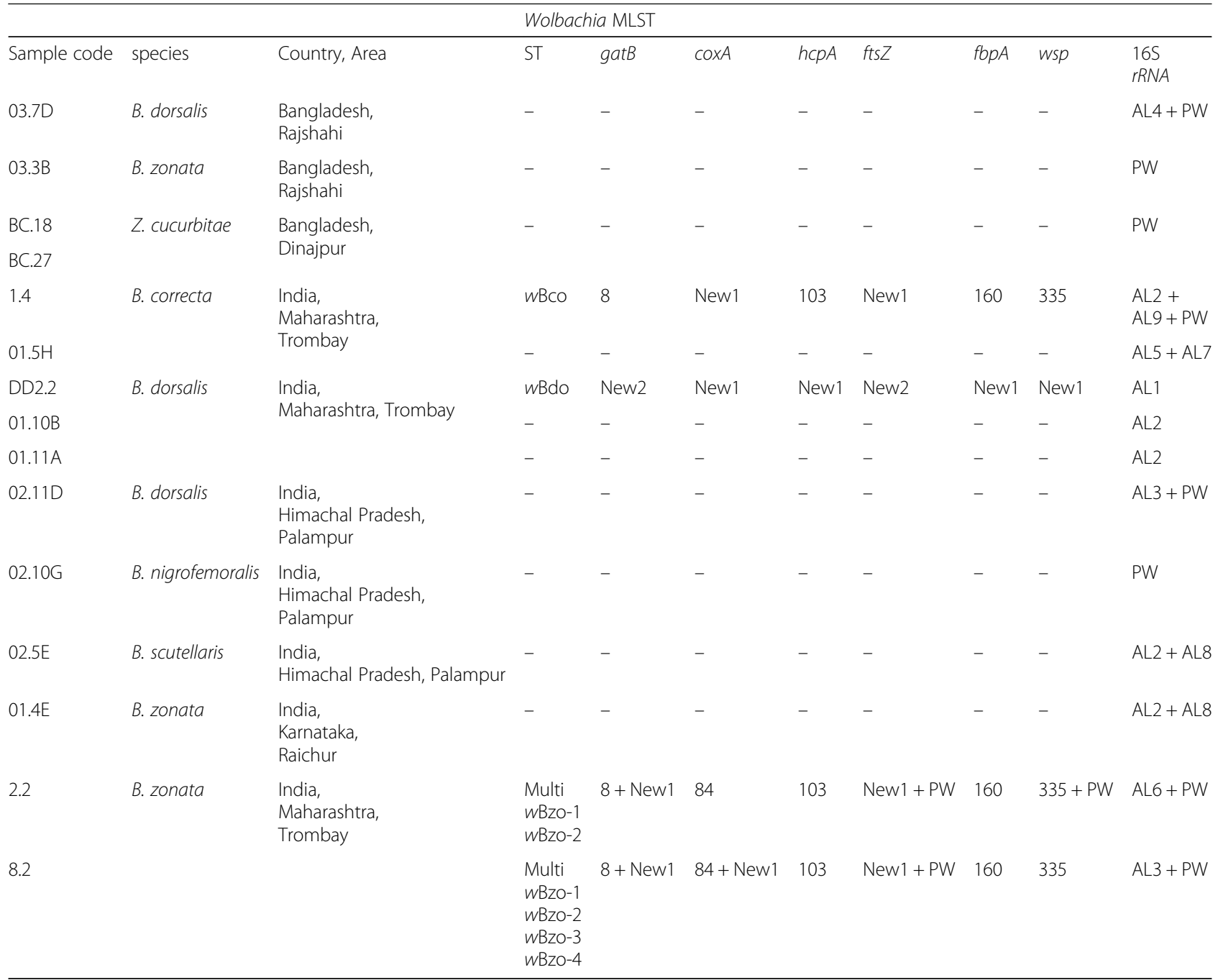

PW: pseudogenized (with deletions) Wolbachia genes

New: new alleles based on MLST data

Multi: multiple potential combinations/ST of alleles

based on the datasets of all MLST (gatB, $\operatorname{coxA} A c p A$, fts $Z$ and $f b p A$ ) and $16 \mathrm{~S} r R N A$ loci. Phylogenetic analysis, based on the $16 \mathrm{~S} r R N A$ gene sequences, revealed that the clear majority of the Wolbachia strains infecting Bactrocera species belonged to supergroup A, except for the strain found in $B$. dorsalis sample DD2.2 from Trombay that fell into supergroup B (Fig. 1). In more detail, based on the 16S rRNA loci, Wolbachia strains infecting Bactrocera species classified into three clusters in supergroup A and one cluster in supergroup B (Fig. 1). The first cluster (A1) includes a Wolbachia strain infecting a B. correcta sample $(01.5 \mathrm{H})$ from Trombay which groups with the strain present in Drosophila melanogaster. The second cluster (A2) is comprised of strains present in samples from India, such as $B$. dorsalis from Palampur and B. zonata from Trombay which are similar to Wolbachia from Glossina morsitans morsitans.
The third cluster (A3) is the largest and contains strains present in samples of $B$. correcta (Trombay), $B$. dorsalis (Trombay), B. scutellaris (Palampur) and B. zonata (Raichur) from India as well as in samples of $B$. dorsalis from Bangladesh (Rajshahi), that are closely related to Wolbachia strains found in Drosophila simulans and Glossina austeni. Finally, the Wolbachia strain infecting sample DD2.2 of B. dorsalis from Trombay, which fell in supergroup B, clusters with the strain from Tetranychus urticae. The same results were also acquired with the phylogenetic analysis based on the concatenated sequences of the MLST genes (Fig. 2). More specifically: (a) the Wolbachia strains $w$ Bzo-3, wBzo-4 (multiple infections in sample 8.2 of $B$. zonata from Trombay) and $w$ Bco (infecting $B$. correcta from Trombay) were classified into a distinct cluster of supergroup $A$, while the Wolbachia strains $w$ Bzo- 1 and $w$ Bzo-2 infecting both $B$. 


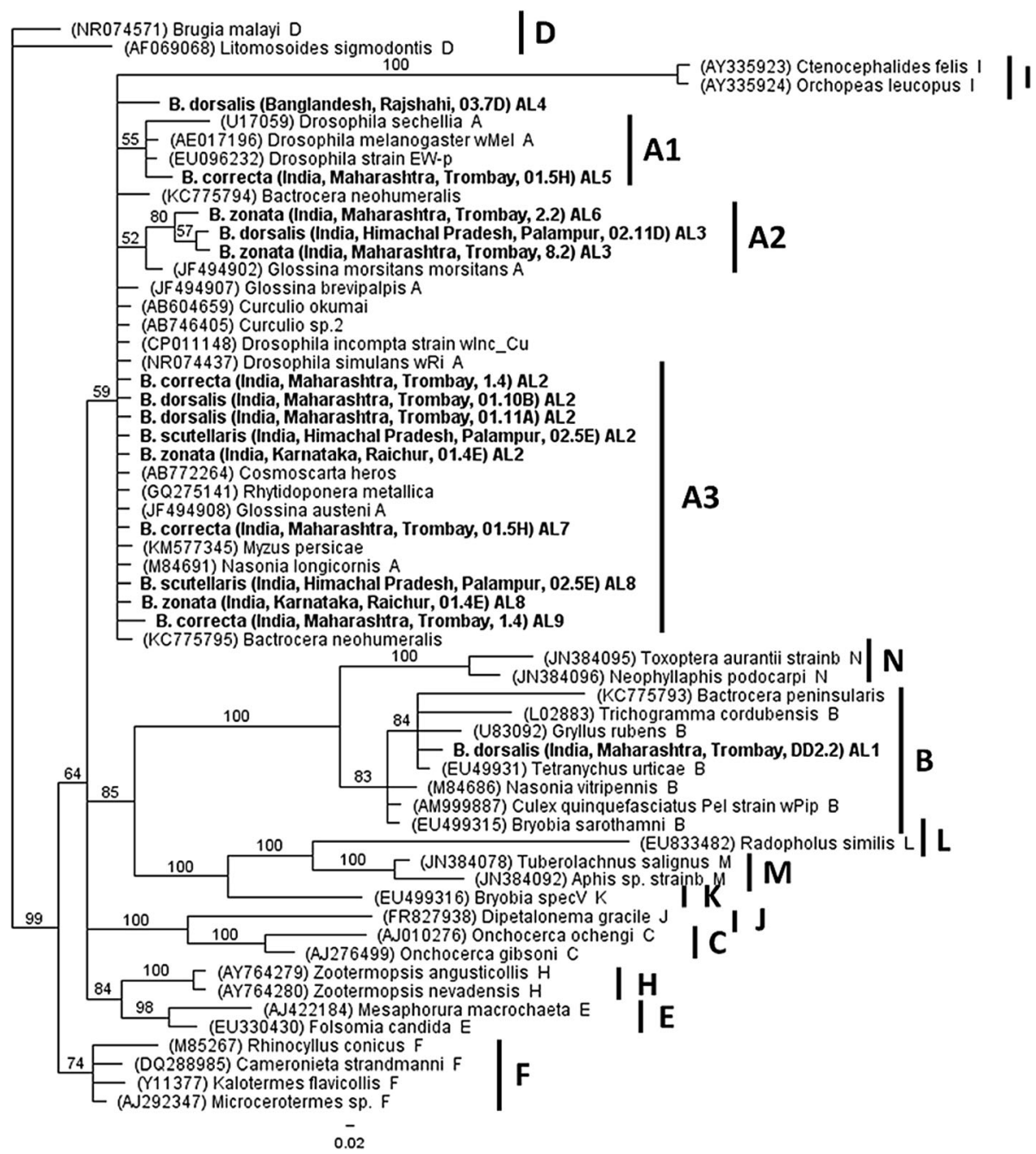

Fig. 1 Bayesian inference phylogeny based on the 16S rRNA gene sequence (438 bp). The 15 Wolbachia strains present in Bactrocera and indicated in bold letters (including 9 Alleles: AL1 to AL9) along with the other strains represent supergroups A, B, C, D, E, F, H, I, J, K, L, M and N. Strains are characterized by the names of their host species and their GenBank accession number. Wolbachia supergroups are shown to the right of the host species names. Bayesian posterior probabilities based on 1000 replicates are given (only values $>50 \%$ are indicated; Brugia malayi used as outgroup)

zonata samples from Trombay (2.2 and 8.2) were assigned into another cluster of supergroup A, (b) the strain $w$ Bdo infecting $B$. dorsalis from Trombay was assigned to supergroup $\mathrm{B}$. The most closely related $\mathrm{Wol}$ bachia strains to $w$ Bzo- 1 and $w$ Bzo- 2 have been detected in Rhagoletis cingulata (ST 158) and Rhagoletis cerasi (ST 158) (Fig. 2).

Phylogenetic analysis based on the 16S rRNA gene revealed that the majority of the Entomoplasmatales infecting Bactrocera and Zeugodacus species clustered with Mesoplasma corruscae and Entomoplasma ellychniae (Fig. 3). These 32 sequences were found in populations of $B$. correcta, B. dorsalis, B. scutellaris and $B$. zonata from various regions of India and in populations of $B$. dorsalis, B. zonata and $Z$. cucurbitae from
Bangladesh. Two sequences from B. zonata samples (Rajshahi) grouped with the closely related Mesoplasma entomophilum cluster. One sequence from B. zonata (Raichur) clustered with Mesoplasma lactucae, in the closely related Entomoplasma group. A strain found in $Z$. cucurbitae from Bangladesh (Dinajpur) was clustered with the Spiroplasma citri-chrysopicola-mirum group and two strains found in a population of $B$. dorsalis from the area of Trombay in India, fell into the Spiroplasma ixodetis group. Finally, the phylogenetic analysis of Cardinium 16S $r R N A$ sequences that were identified in two populations of $B$. dorsalis (Dinajpur and Palampur) were grouped with Cardinium species infecting Encarsia pergandiella and Plagiomerus diaspidis that compose group A of Cardinium strains (Fig. 4). 


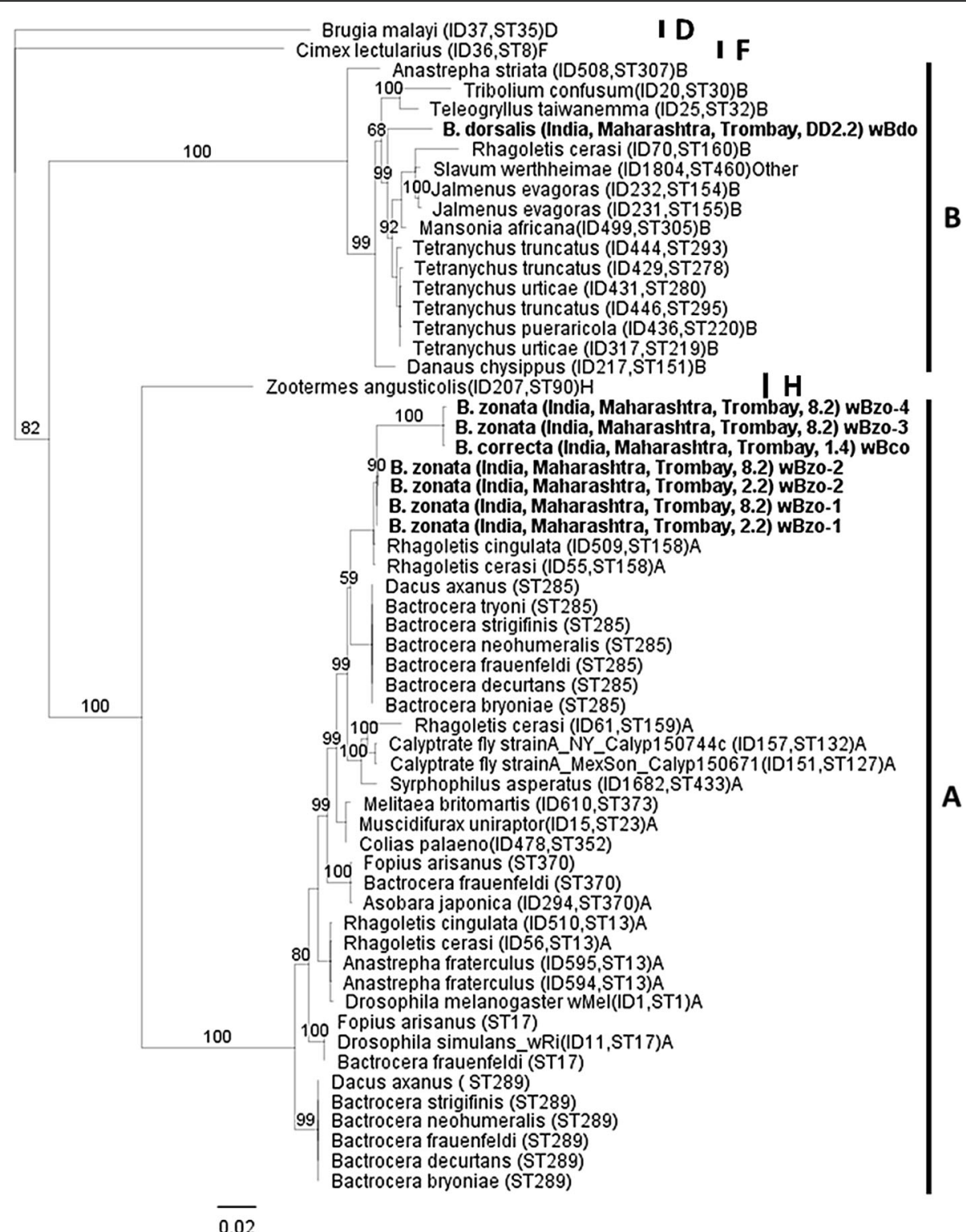

Fig. 2 Bayesian inference phylogeny based on the concatenated MLST data (2079 bp). The eight Wolbachia strains present in Bactrocera are indicated in bold letters, while all the other strains represent supergroups A, B, D, F and H. Strains are characterized by the names of their host species and ST number from the MLST database. Wolbachia supergroups are shown to the right of the host species names. Bayesian posterior probabilities based on 1000 replicates are given (only values $>50 \%$ are indicated; Brugia malayi used as outgroup)

\section{Detection of Wolbachia pseudogenes}

The presence of two distinct PCR amplification products was observed for the 16S rRNA gene in samples from four Bactrocera populations during the Wolbachia-specific 16S $r R N A$-based screening (Table 3). The first product had the expected $438 \mathrm{bp}$ size while the second was $296 \mathrm{bp}$ (Fig. 5a). Interestingly, the populations of $B$. nigrofemoralis from Palampur, India and B. zonata from Rajshahi, Bangladesh were found to contain only the smaller pseudogenized sequence. On the contrary, other samples from India including, $B$. correcta (sample $01.5 \mathrm{H}$ ) and $B$. dorsalis from Trombay, B. scutellaris from
Palampur and B. zonata from Raichur, contained only the expected $438 \mathrm{bp}$ fragment (Table 3). When sequenced, both PCR products appeared to be of Wolbachia origin. The $438 \mathrm{bp}$ product corresponded to the expected 16S rRNA gene fragment, while the shorter product contained a deletion of $142 \mathrm{bp}$ (Fig. 5a). The 296 bp short version of the gene was detected in seven individuals from various Bactrocera species, including $B$. correcta, B. dorsalis, B. nigrofemoralis and B. zonata. Three different types of deletions were found, with minor changes in their nucleotide sequence compared to the cytoplasmic Wolbachia 16S rRNA gene fragment 


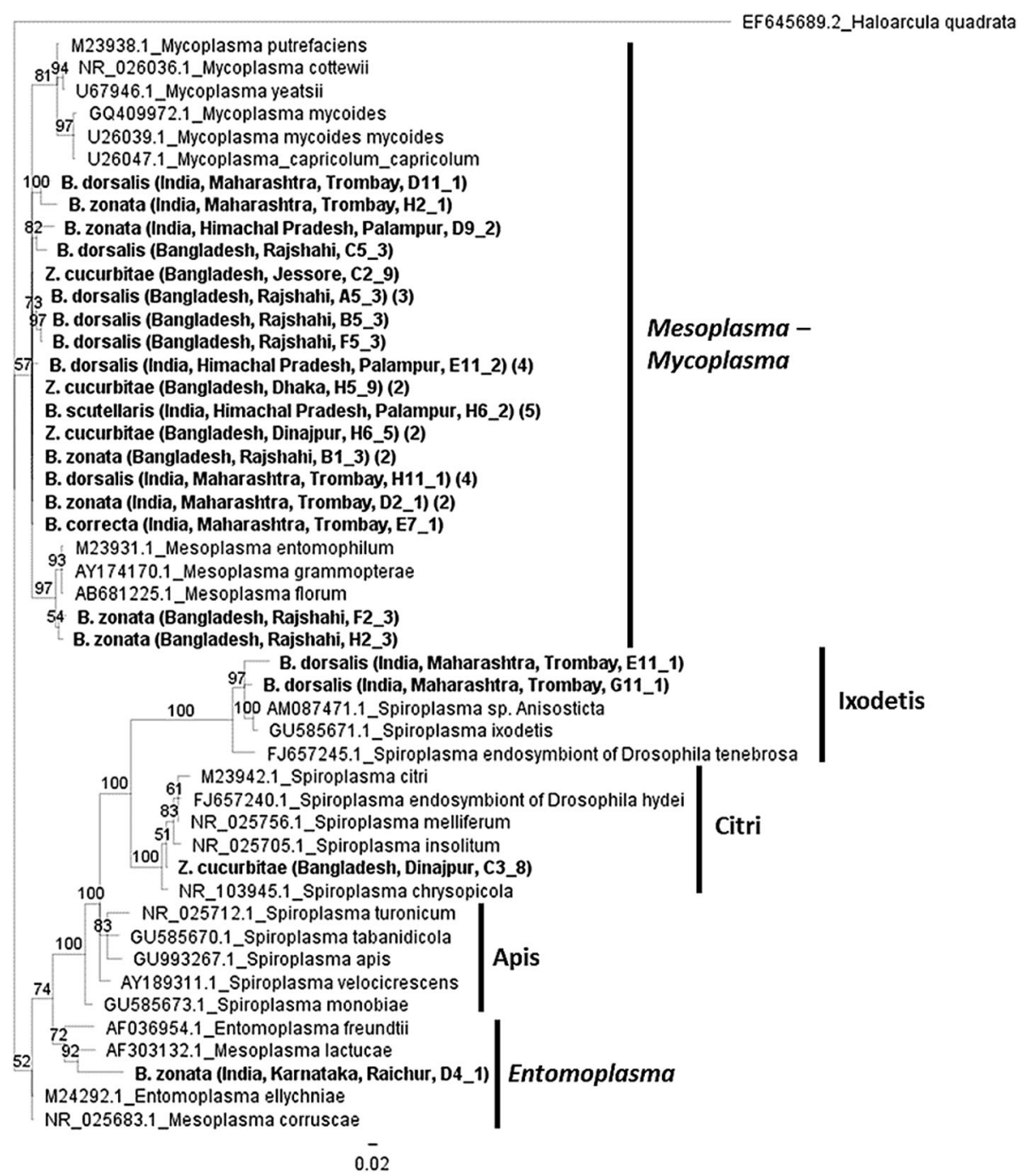

Fig. 3 Bayesian inference phylogeny based on the Entomoplasmatales $16 \mathrm{~S}$ rRNA gene sequence (301 bp). The strains present in Bactrocera and Z. cucurbitae are indicated in bold letters. Most samples represent the Entomoplasma and Mesoplasma-Mycoplasma groups while three sequences represent the Ixodetis and Citri groups of Spiroplasma. The Ixodetis, Citri and Apis clades are shown to the right of the Spiroplasma species names. Bayesian posterior probabilities based on 1000 replicates are given (only values $>50 \%$ are indicated; Haloarcula quadrata used as outgroup). For each strain, their GenBank accession number is also given on the left. Two sequences were removed due to short length (one from $B$. dorsalis and one from $Z$. tau). Parentheses on the right of the name indicate number of sequences from that population

found in Drosophila melanogaster and various Bactrocera species in this study (Fig. 5a). Zeugodacus cucurbitae from Dinajpur, Bangladesh contained only pseudogenized Wolbachia 16S rRNA gene sequences. In this case, however the deletion was only $68 \mathrm{bp}$ and the resulting pseudogene had a size of $370 \mathrm{bp}$ (Fig. 5a). The presence of distinct amplicons was also observed during Wolbachia MLST analysis for genes ftsZ and wsp. In both cases, apart from the expected PCR product, a smaller fragment was also detected (Fig. 5b, c). Multiple $f t s Z$ gene products were found in two samples (2.2 and 8.2) belonging to the population of $B$. zonata from Trombay, India. Two different short amplicons were observed. Sequence analysis revealed that the large product had the expected size of $524 \mathrm{bp}$ while the short ones were either 512 bp or 419 bp long (Fig. 5b). The 512 bp fragment contained a small deletion of $12 \mathrm{bp}$ while the $419 \mathrm{bp}$ one, a much larger of $105 \mathrm{bp}$. The $419 \mathrm{bp}$ fragment was only detected in sample 8.2. In the case of the $512 \mathrm{bp}$ fragment, two different variants were found with minor changes in their sequence (Fig. 5b). Two distinct PCR products were also observed during amplification of the wsp gene in sample 2.2 of B. zonata from India (Trombay) (Fig. 5c). After sequence analysis, the larger product appeared to have the expected $606 \mathrm{bp}$ size while the second was significantly smaller, consisting of only $155 \mathrm{bp}$. Two such pseudogenes were found in this case, with minor differences in their sequence (Fig. 5c). 


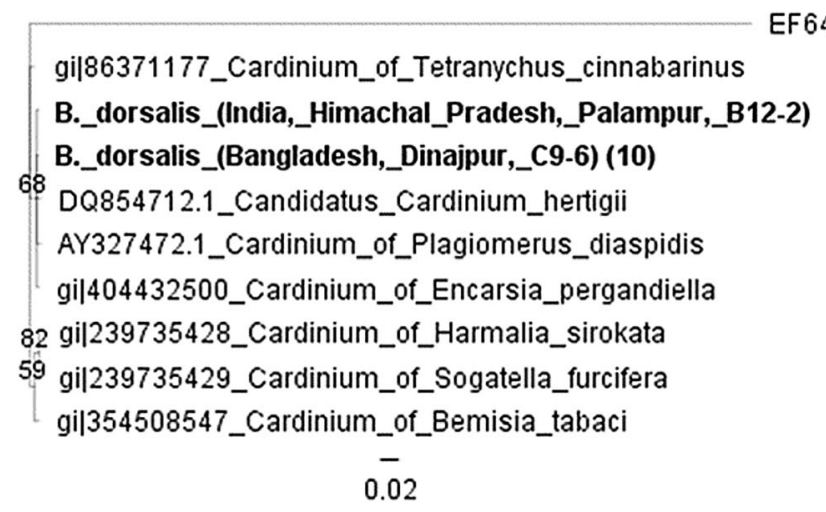

Fig. 4 Bayesian inference phylogeny based on the Cardinium 16S rRNA gene sequence (354 bp). The strains present in Bactrocera are indicated in bold letters. The 11 sequences from B. dorsalis and one from Z. tau (removed due to shorter length) group with Cardinium sequences found in Encarsia pergandiella and Plagiomerus diaspidis. Bayesian posterior probabilities based on 1000 replicates are given (only values $>50 \%$ are indicated; Haloarcula quadrata used as outgroup). For each strain, their GenBank accession number is also given on the left. Parentheses on the right of the name indicate number of sequences from that population

\section{(A)}

Drosophila melanogaster wMel

1168931

1169135 |

1169278 |

Bactrocera Cytoplasmic allele 1

Variant 1a

Variant $1 \mathrm{~b}$

Variant 1c

Variant 2

(B)

Drosophila melanogaster wMel

B. zonata cytoplasmic (2.2)

B. zonata cytoplasmic (8.2)

Variant 1a (2.2)

Variant $1 \mathrm{~b}(8.2)$

Variant $2(8.2)$

(C)

Drosophila melanogaster wMel

Bactrocera cytoplasmic allele 335

Variant 1a (2.2)

Variant $1 \mathrm{~b}(2.2)$

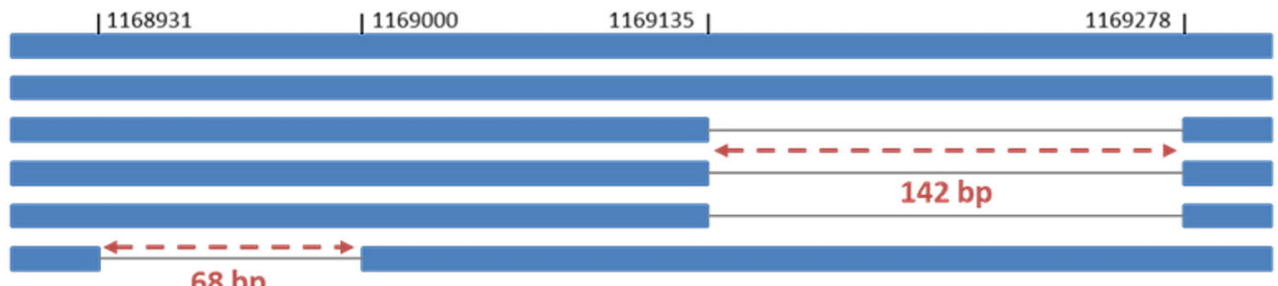

$68 \mathrm{bp}$

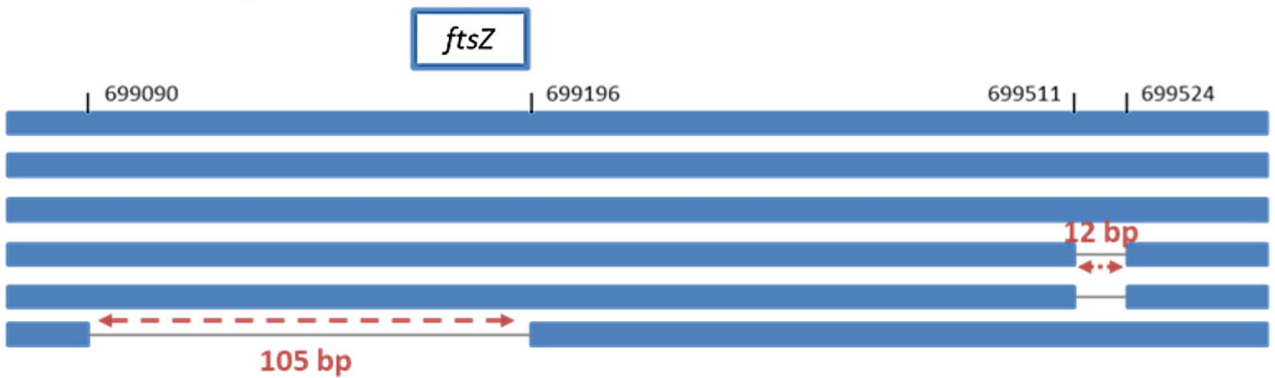

105 bp

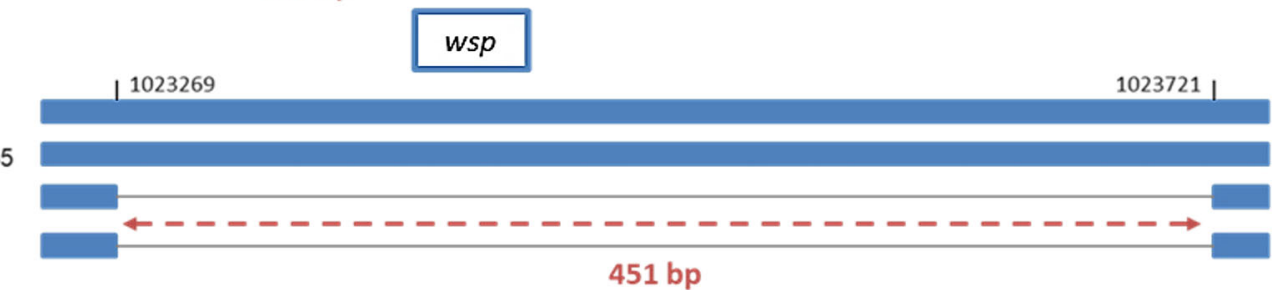

Fig. 5 Overview of three Wolbachia pseudogenes carrying deletions of various sizes. The $16 \mathrm{~S}$ rRNA, ftsZ and wsp gene fragments of Wolbachia chromosomal insertions sequenced from natural Bactrocera and Zeugodacus populations aligned with the corresponding regions of strain wMel and Wolbachia strains infecting Bactrocera flies (cytoplasmic). Grey lines represent the deletion region. The black numbers show the positions before and after the deletions in respect to the wMel genome. The red arrows and numbers indicate the size of deletion in base pairs. Variants exhibit small number of SNPs. a Variant 1a: B. zonata (Bangladesh, Rajshahi, 03.3B), B. correcta (India, Trombay, 1.4), B. dorsalis (India, Palampur, 02.11D), B. nigrofemoralis (India, Palampur, 02.10G), B. zonata (India, Trombay, 2.2). Variant 1b: B. dorsalis (Bangladesh, Rajshahi, 03.7D), B. dorsalis (India, Palampur, 02.11D), B. zonata (India, Trombay, 8.2). Variant 1C: B. correcta (India, Trombay, 1.4). Variant 2: Z. cucurbitae (Bangladesh, Dinajpur, 07.10H). b Deletions in the ftsZ gene were identified in two B. zonata samples, B. zonata (India, Trombay, 2.2) and B. zonata (India, Trombay, 8.2). Sample 8.2 carried two different types of deletions. (C) B. zonata (India, Trombay, 2.2) contained wsp pseudogenes with two different types of deletions 


\section{Discussion}

In this study, Wolbachia, Entomoplasmatales and Cardinium infections were identified in several Bactrocera and Zeugodacus species. Interestingly, none of the examined populations contained sequences belonging to Arsenophonus.

\section{Infections prevalence}

The prevalence of Wolbachia infections was found to vary between different species. For the first time, infections were detected in B. scutellaris and B. zonata. In the case of $B$. correcta, a previous study on wild samples from Thailand reported a higher infection rate (50\%) than the one observed in our work (33\%), but was based on only two screened individuals [94]. Contrary to the infection rate we detected in $B$. dorsalis (13.2\%), most wild and laboratory populations examined up to date, were found to harbor no Wolbachia infections [94-96]. However, there are two cases of active Wolbachia infections that have been reported in $B$. dorsalis from Thailand. One is a low rate infection $(0.9 \%$; 2 individuals out of 222) and the other shows medium prevalence (50\%) but is based only on one infected sample [94]. On the other hand, no Wolbachia infections were present in B. minax, B. nigrofemoralis, D. longicornis, Z. cucurbitae and $Z$. tau. It is noteworthy that previous studies reported infections, but overall with very low prevalence, in Z. cucurbitae (4.2\%) and Z. tau (1\%) [94]. Recently, Wolbachia endosymbiont of Culex quinquefasciatus Pel was detected as the dominant species, with $\sim 98 \%$ prevalence, in all the life stages studied in samples of B. latifrons (Hendel) from Malaysia using next-generation sequencing [97]. This occurrence is notably higher than any other Bactrocera species originating from Southeast Asia and Oceania.

Most of the Wolbachia-infected populations were found in India, in areas located in the far North (Palampur), close to the West coast (Trombay) as well as in the South (Raichur). Only one infected population was detected in Bangladesh, close to the city of Rajshahi, on the western border with India. In the case of B. zonata, the presence of Wolbachia decreased and eventually the infection was lost as we moved towards the North and away from the equator. Otherwise, this trend could mean that the infection is currently spreading from South to North. At the same time, infections in $B$. dorsalis exhibited the exact opposite behavior. The low prevalence infection detected in the population originating from Rajshahi, in western Bangladesh, close to the border with India, could be the result of a current spreading from the neighboring infected Indian populations. No individuals from Raichur were screened, so the picture of the infection in $B$. dorsalis further to the South is incomplete. Infected populations of $B$. correcta followed a similar pattern to $B$. dorsalis. In this case, however, no population from Northern India (Palampur) was included in the screen. Finally, it was impossible to determine a trend in the case of $B$. scutellaris since the only infected population was found in the North of India (Palampur).

Low density $(<10 \%)$ Entomoplasmatales infections were detected in multiple Zeugodacus and Bactrocera species. Previous screenings of laboratory populations of five Bactrocera species did not reveal any infections with members of the Entomoplasmatales [95]. Spiroplasma infections, the only genus within the order with species known to induce reproductive phenotypes, were identified in $B$. dorsalis and $Z$. cucurbitae with much lower frequencies $(\sim 1 \%)$ compared to other fly species belonging to the genera of Drosophila $(0-53 \%)[38,98]$ Glossina (5.8-37.5\%) [75] and Phlebotomus (12.5\%) [99]. The geographical distribution of infected populations appeared to be widespread in various areas of Bangladesh and India. In both B. dorsalis and B. zonata, subtropical and tropical populations were generally characterized by similar infection rates with little fluctuation, suggesting that geography does not influence the dispersion of infections. For the remaining fruit fly species infected with Entomoplasmatales, we could not extract any useful information about the geographical distribution of infections either due to the presence of only one infected population or due to the proximity of infected populations.

Populations infected with Cardinium originated only from subtropical regions and harbored either medium or low prevalence infections. Previously, 244 species of flies belonging to the Empidoidea (Order: Diptera), which consists of four families such as the long-legged flies (Family: Dolichopodidae) and the dance flies (Family: Hybotidae), were found to contain Cardinium infections in only ten species, with an incidence rate of $4 \%$ [28]. A similar study in various arthropods did not identify any Cardinium sequences in the seven families of Diptera studied [33] while laboratory populations of various Bactrocera species were also free of Cardinium infections [95]. However, higher occurrence of Cardinium was identified in Culicoides biting midge species (Diptera: Ceratopogonidae) with infection rates reaching up to $50.7,72$ or $100 \%$ [80, 100]. It seems that a wide range of Cardinium infections can be found in different fly species.

\section{Genotyping - phylogeny}

The 16S rRNA, MLST and wsp-based sequence analysis results are in accordance with a previous study that was based on $16 \mathrm{~S} r R N A$ and wsp phylogeny, in which Wolbachia strains infecting various Bactrocera species from Australia, like B. bryoniae (Tryon), B. decurtans (May), B. 
frauenfeldi (Schiner) and B. neohumeralis (Hardy), were clustered in supergroup A [96]. Another study, based on the $f t s Z$ and wsp genes, identified strains belonging to both supergroups $A$ and $B$, in samples from Thailand from various species including, $B$. ascita (Hardy), B. diversa (Coquillett) and B. dorsalis [101], even though a previous work on the same samples found strains belonging mostly to supergroup B, except for those found in B. tau (now Z. tau) that belonged to supergroup A [94]. The phylogenetic analysis based on the 16S rRNA gene sequence revealed the presence of closely related Wolbachia strains in different Bactrocera species (Fig. 1), which could be the result of horizontal transmission between insect species, as has been previously reported in the case of the parasitic wasp genus Nasonia and its fly host Protocalliphora [102] as well as in other insects [70, 103-105]. In addition, populations of various species, including B. correcta, B. dorsalis, B. scutellaris and $B$. zonata from different locations harbor very closely related Wolbachia strains, suggesting that the geographical origin of their hosts did not lead to Wolbachia strain divergence. However, some divergence was observed between samples of the same species (e.g. $B$. correcta) from the same population (Trombay; subgroups $\mathrm{A} 1$, and $\mathrm{A} 3$ ), and between different populations of a species (e.g. B. zonata; Trombay and Raichur; A2 and A3 respectively). Distantly related Wolbachia strains were seen between different $B$. dorsalis populations, but also in samples from the same population (Trombay, A3 and B). Strains belonging to supergroups $\mathrm{A}$ and $\mathrm{B}$ have been previously found to occur in the same species $[102,106]$. The same picture, with closely related strains between different species and a distantly related strain from $B$. dorsalis from Trombay, was also seen in the MLST/wsp based phylogeny. Some degree of divergence was also observed between $B$. zonata samples of the same population (Trombay) similar to the one observed in the $16 \mathrm{~S}$ rRNA gene-based phylogeny.

Phylogenetic analysis on the 16S rRNA gene sequences revealed that most Entomoplasmatales strains grouped with the closely related species Mesoplasma corruscae and Entomoplasma ellychniae. Overall, three samples were found to carry Spiroplasma infections. Two of the 16S $r R N A$ gene sequences were classified into the ixodetis group and one into the citri-chrysopicola-mirum group. Spiroplasma strains infecting tsetse flies were also clustered in the citri-chrysopicola-mirum group [75]. On the other hand, S. ixodetis is mostly found in ticks [107109]. All Cardinium strains described in this study were similar to the strain infecting the parasitic wasp Encarsia pergandiella (Order: Hymenoptera). Similar strains were also found in other parasitic wasps of the genus Encarsia as well as in armored scale insects (Order: Hemiptera) like Aspidiotus nerii and Hemiberlesia palmae [37].

\section{Wolbachia pseudogenes}

In the present study, three Wolbachia genes, $16 \mathrm{~S}$ rRNA, fts $Z$ and $w s p$, were found to harbor deletions of various sizes in their sequence. The most common pseudogenes were identified in the case of the $16 \mathrm{~S} r R N A$ gene, in four Bactrocera species and Z. cucurbitae (Fig. 5a) while shorter copies of the ftsZ and wsp genes were found only in B. zonata. It is worth mentioning that pseudogenized sequences were found both in populations that harbored presumably active Wolbachia infections and in uninfected ones. Interestingly, the $16 \mathrm{~S} r R N A$ and ftsZ pseudogenes were similar to those described previously in Glossina species [86], which were shown to be incorporated in the host genome. The similarity in sequence with the Glossina pseudogenes, along with the lack of amplification of all marker genes (MLST and wsp), could suggest that the identified pseudogenes may be integrated into the genome of Bactrocera flies. Wolbachia pseudogenes (16S rRNA, wsp, coxA, hcpA and $f b p A$ ) have been previously identified in two Bactrocera species (B. peninsularis (Drew \& Hancock) and B. perkinsi) from tropical Australian populations with amplification results also suggesting horizontal gene transfer to the host genome [96]. Even though horizontal gene transfer is much more common between prokaryotes, many cases have been described between endosymbiotic bacteria and their insect hosts [82]. These interactions may have significant impact on the genomic evolution of the invertebrate hosts. Pseudogenized Wolbachia sequences and horizontal transfer events have been reported in various Wolbachia-infected hosts [83-86, 89, 90, 92, 93]. It is worth noting that in some cases horizontally transferred Wolbachia genes are expressed from the host genome, as reported in the mosquito Aedes aegypti and in the pea aphid Acyrthosiphon pisum [89, 92, 93].

\section{Conclusions}

Wolbachia, Cardinium, Spiroplasma and its close relatives, Entomoplasma and Mesoplasma, are present in wild populations of Bactrocera and Zeugodacus species from Southeast Asia. Strain characterization and phylogenetic analyses were performed primarily with the $16 \mathrm{~S}$ rRNA gene and additionally, in the case of Wolbachia, with the wsp and MLST gene markers, revealing the presence of supergroup A and B Wolbachia strains along with new and previously identified Wolbachia MLST and wsp alleles, Spiroplasma strains belonging to the citri-chrysopicola-mirum and ixodetis groups as well as sequences clustering with Mesoplasma and Entomoplasma species, and finally group A Cardinium species similar to those infecting Encarsia pergandiella and 
Plagiomerus diaspidis. Even though the geographical map of infections is incomplete, it seems that Wolbachia are more common in Indian populations and possibly spreading to neighboring countries, while Entomoplasmatales infections are widespread in both Indian and Bangladeshi populations. Fruit flies infected with these bacterial taxa were found in both tropical and subtropical regions. On the other hand, Cardinium infections were less common and were only found in subtropical populations. The detection of Wolbachia pseudogenes, containing deletions of variable size, implies putative events of horizontal gene transfer in the genome of the tephritid fruit fly populations studied which could be remnants of past infections. Further study of additional species and wild populations could provide a more detailed report of the infection status for these specific endosymbiotic bacteria that may function as reproductive parasites. The detailed characterization of existing strains could shed more light on the host-symbiont interactions, which could be potentially harnessed for the enhancement of the sterile insect technique (SIT) and related techniques as components of area-wide integrated pest management (AW-IPM) strategies for the control of insect pest populations.

\section{Methods}

Sample collection, preparation and DNA extraction

Analyzed samples belonged to nine species of fruit flies from three different Tephritidae genera: Bactrocera, Dacus and Zeugodacus. A total of 801 adult male fruit flies were collected from 30 natural populations originating from various regions of Bangladesh, China and India and stored in absolute ethanol Fig. 6 (Table 1). DNA extraction was performed immediately after the arrival of the samples in the laboratory of Molecular Genetics and Microbiology at the University of Patras. Total DNA was extracted from the whole body of adult flies using the NucleoSpin ${ }^{\circ}$ Tissue kit (Macherey-Nagel $\mathrm{GmbH} \& \mathrm{Co} . \mathrm{KG}$ ) following the manufacturer's instructions. Prior to extraction, the insects were washed with sterile deionized water to remove any traces of ethanol. Each sample contained one fly $(n=1)$. Extracted DNA was stored at $-20^{\circ} \mathrm{C}$.

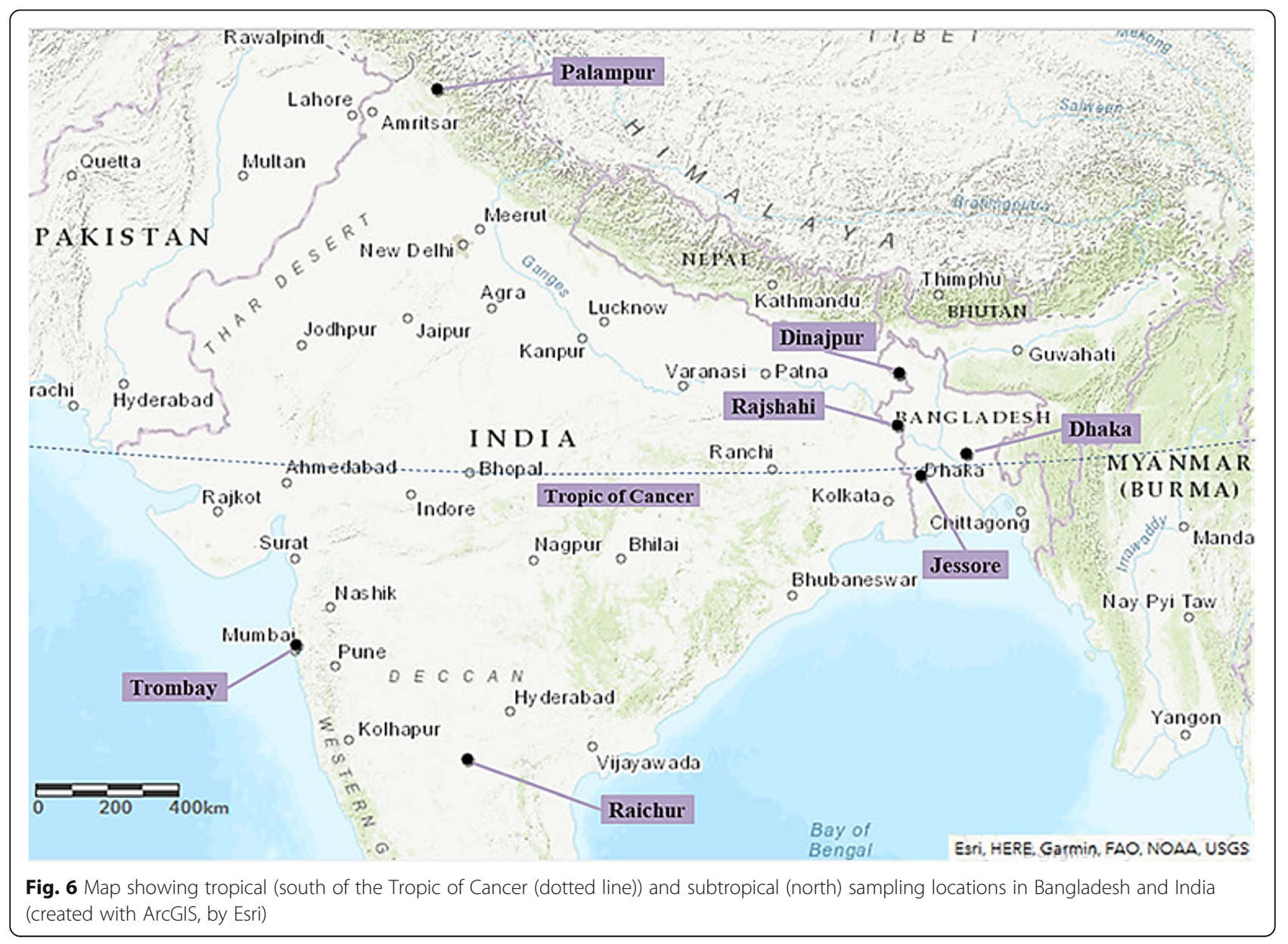




\section{PCR screening and Wolbachia MLST}

The presence of reproductive symbiotic bacteria that belong to the genera Wolbachia, Spiroplasma (and the other two genera of the Entomoplasmatales, Entomoplasma and Mesoplasma), Cardinium and Arsenophonus in natural populations of tephritid fruit flies was investigated with a $16 \mathrm{~S} r R N A$ gene-based PCR assay. A fragment of variable size (301-600 bp) was amplified with the use of specific primers for each bacterial genus (Additional file 2). In the case of Wolbachia strains, the specific 16S rRNA PCR assay that was employed was described previously [86]. Prior to screening, the mitochondrial 12S rRNA gene was used as positive control for PCR amplification. A $377 \mathrm{bp}$ fragment of the gene was amplified in all samples tested with the primers 12SCFR and 12SCRR [110]. Also, amplification of an approximately $800 \mathrm{bp}$ long fragment of host mitochondrial cytochrome oxidase I (COI) gene was carried out with primers "Jerry" and "Pat" [111] in order to perform molecular characterization of the samples tested and to confirm successful DNA extraction (Additional file 3). Amplification was performed in $20 \mu \mathrm{l}$ reactions using KAPA Taq PCR Kit (Kapa Biosystems). Each reaction contained $2 \mu \mathrm{l}$ of 10X KAPA Taq Buffer, $0.2 \mu \mathrm{l}$ of dNTP solution ( $25 \mathrm{mM}$ each), $0.4 \mu \mathrm{l}$ of each primer solution $(25 \mu \mathrm{M}), 0.1 \mu \mathrm{l}$ of KAPA Taq DNA Polymerase solution $(5 \mathrm{U} / \mu \mathrm{l}), 1 \mu \mathrm{l}$ from the template DNA solution and was finalized with $15.9 \mu \mathrm{l}$ of sterile deionized water. For each set of PCR reactions performed, the appropriate negative (no DNA) and positive controls were also prepared. The PCR protocol was comprised of an initial denaturation step at $95^{\circ} \mathrm{C}$ for $5 \mathrm{~min}$, followed by $35 \mathrm{cy}$ cles of denaturation for $30 \mathrm{~s}$ at $95^{\circ} \mathrm{C}$, annealing for $30 \mathrm{~s}$ at the required annealing temperature $\left(\mathrm{T}_{\mathrm{a}}\right)$ for every pair of primers $\left(54{ }^{\circ} \mathrm{C}\right.$ for Wolbachia, $56{ }^{\circ} \mathrm{C}$ for Arsenophonus and Cardinium, $58^{\circ} \mathrm{C}$ for Spiroplasma, $54^{\circ} \mathrm{C}$ for the $12 \mathrm{~S} r R N A$ gene and $49^{\circ} \mathrm{C}$ for mtCOI) and extension at $72{ }^{\circ} \mathrm{C}$ for $1 \mathrm{~min}$. A final extension step was performed at $72{ }^{\circ} \mathrm{C}$ for $5 \mathrm{~min}$.

In order to genotype the Wolbachia strains present in infected specimens (Table 3 ), fragments of the MLST (gatB, $\operatorname{cox} A, h c p A, f b p A$ and $f t s Z$ ) and wsp genes were amplified with the use of their respective primers [74] (Additional file 2). Ten Wolbachia-infected populations (three Bangladeshi and seven Indian) were initially selected for genotyping using the MLST and wsp genes. Efforts were made to amplify the MLST genes in all selected samples, however, most PCRs failed, resulting in the successful amplification of all the MLST genes for only four samples (Table 3). Due to these difficulties, the characterization of the bacterial strains present in the remaining infected flies was limited to the $16 \mathrm{~S} r R N A$ gene. The four samples that were amplified belonged to three Bactrocera species, B. correcta, B. dorsalis, and B. zonata (Table 3). Amplification was performed in $20 \mu \mathrm{l}$ reactions with the following PCR mix: $2 \mu \mathrm{l}$ of 10X KAPA Taq Buffer, $0.2 \mu \mathrm{l}$ of dNTP mixture ( $25 \mathrm{mM}$ each), $0.4 \mu \mathrm{l}$ of each primer solution $(25 \mu \mathrm{M}), 0.1 \mu \mathrm{l}$ of KAPA Taq DNA Polymerase solution $(5 \mathrm{U} / \mu \mathrm{l}), 1 \mu \mathrm{l}$ from the template DNA solution and $15.9 \mu \mathrm{l}$ of sterile deionized water. PCR reactions were performed using the following program: $5 \mathrm{~min}$ of denaturation at $95^{\circ} \mathrm{C}$, followed by 35 cycles of $30 \mathrm{~s}$ at $95^{\circ} \mathrm{C}, 30 \mathrm{~s}$ at the appropriate temperature for each primer pair $\left(52^{\circ} \mathrm{C}\right.$ for $f t s Z, 54{ }^{\circ} \mathrm{C}$ for gat $B, 55^{\circ} \mathrm{C}$ for coxA $56^{\circ} \mathrm{C}$ for $h c p A, 58^{\circ} \mathrm{C}$ for $f b p A$ and wsp), $1 \mathrm{~min}$ at $72^{\circ} \mathrm{C}$ and a final extension step of 10 $\min$ at $72^{\circ} \mathrm{C}$.

Due to products of variable size and the presence of multiple infections, we selected one representative sample from each Wolbachia-infected species population and cloned the PCR products of the Wolbachia $16 \mathrm{~S} r R N A$, wsp and MLST genes (Table 3) into a vector (pGEM-T Easy Vector System, Promega) according to the manufacturer's instructions. The ligation product was used to transform DH5 $\alpha$ competent cells, which were plated on ampicillin/X-gal selection Petri dishes. At least three clones were amplified by colony PCR [112] with primers T7 and SP6 (Thermo Fischer Scientific Inc.). Amplification was performed in $50 \mu \mathrm{l}$ reactions each containing: $5 \mu \mathrm{l}$ of 10X KAPA Taq Buffer, $0.4 \mu \mathrm{l}$ of dNTP mixture ( $25 \mathrm{mM}$ each), $0.2 \mu \mathrm{l}$ of each primer solution $(100 \mu \mathrm{M}), 0.2 \mu \mathrm{l}$ of KAPA Taq DNA Polymerase solution $(5 \mathrm{U} / \mu \mathrm{l})$ and $44 \mu \mathrm{l}$ of sterile deionized water. The PCR protocol consisted of $5 \mathrm{~min}$ of denaturation at $95^{\circ} \mathrm{C}$, followed by 35 cycles of $30 \mathrm{~s}$ at $95^{\circ} \mathrm{C}, 30 \mathrm{~s}$ at $53^{\circ} \mathrm{C}, 2 \mathrm{~min}$ at $72^{\circ} \mathrm{C}$ and a final extension step at $72^{\circ} \mathrm{C}$ for $10 \mathrm{~min}$.

\section{Sample purification and sanger sequencing}

Throughout the experimental procedure, imaging of the desired amplification products was performed in a Gel $\operatorname{Doc}^{\mathrm{Tm}} \mathrm{XR}+$ system (Bio-Rad) after loading $5 \mu \mathrm{l}$ from each PCR reaction on $1.5 \%(\mathrm{w} / \mathrm{v})$ agarose gels and separating them by electrophoresis. Purification of the PCR products was carried out with a $20 \%$ PEG, $2.5 \mathrm{M} \mathrm{NaCl}$ solution as previously described [113]. The concentration of purified PCR product was measured with a Quawell Q5000 micro-volume UV-Vis spectrophotometer. Purified PCR products were sequenced using the appropriate primers in each case (Additional file 2) while cloned Wolbachia PCR products were sequenced with the universal primers T7 and SP6. In this case, at least three transconjugants were sequenced as previously described [86]. A dye terminator-labelled cycle sequencing reaction was conducted with the BigDye Terminator v3.1 Cycle Sequencing Kit (Applied Biosystems). Reaction products were purified using an ethanol/EDTA protocol according to the manufacturer's instructions (Applied Biosystems) 
and were analyzed in an ABI PRISM 3500 Genetic Analyzer (Applied Biosystems).

\section{Phylogenetic analysis}

All gene sequences used in this study were aligned using MUSCLE, [114] with the default algorithm parameters, as implemented in Geneious 6.1 .8 [115] and manually edited. Statistical significance of pairwise comparisons of infection prevalence between different species of fruit flies, areas or countries were calculated with chi-squared tests which were performed with $\mathrm{R}$ 3.5.1 [116]. The null hypothesis $\left(H_{0}\right)$ assumed that the variables (infection status between different species, areas or countries) were independent, and the significance level was equal to 0.05 . $P$-values are presented in the text only for comparisons that show statistical significance. Alignments used in phylogenetic analyses were performed with MUSCLE [114] using the default algorithm parameters, as implemented in Geneious 6.1.8 [115]. Phylogenetic analyses of the 16S rRNA gene sequences and the concatenated sequences of the protein-coding MLST genes $(\operatorname{cox} A, f b p A$, ftsZ, gatB and $h c p A$ ) were based on Bayesian Inference (BI). Bayesian analyses were performed with MrBayes 3.2.1 [117]. The evolutionary model was set to the Generalised Time Reversible (GTR) model with gammadistributed rate variation and four gamma categories used. The parameters for the Markov Chain Monte Carlo (MCMC) method included four heated chains, with the temperature set to 0.2 , which were run for 1 , 000,000 generations. The first 10,000 generations were discarded, and the cold chain was sampled every 100 generations. Also, posterior probabilities were computed for the remaining trees. All phylogenetic analyses were performed with Geneious [115]. All MLST, wsp and 16S rRNA gene sequences generated in this study have been deposited into GenBank under accession numbers MK045503-MK045529 and MK053669-MK053774.

\section{Supplementary information}

Supplementary information accompanies this paper at https://doi.org/10. 1186/s12866-019-1653-x.

Additional file 1. Prevalence of reproductive bacteria in tephritid fruit fly populations from Bangladesh, China and India using a 16S rRNA genebased PCR screening approach. Red values in the heat map indicate high occurrence and blue values low. For each genus the absolute number and the percentage (in parentheses) of infected individuals are given. The last column on the right ("Total*") indicates the total occurrence of all three Entomoplasmatales genera.

Additional file 2. Genes and PCR primers used.

Additional file 3. Bayesian inference phylogeny tree based on host mtDNA COI ( $~ 800$ bp). Bayesian posterior probabilities based on 1000 replicates are given (only values $>50 \%$ are indicated).

\section{Abbreviations}

AW-IPM: Area-Wide Integrated Pest Management; CFB: Cytophaga-

Flavobacterium-Bacteroides; Cl: Cytoplasmic Incompatibility; GTR: Generalised
Time Reversible; HGT: Horizontal Gene Transfer; HVR: Hypervariable Region; MCMC: Markov Chain Monte Carlo; MLST: Multi Locus Sequence Typing; SIT: Sterile Insect Technique; ST: Sequence Type

\section{Acknowledgements}

Not applicable.

\section{About this supplement}

This article has been published as part of BMC Microbiology Volume 19 Supplement 1, 2019: Proceedings of an FAO/IAEA Coordinated Research Project on Use of Symbiotic Bacteria to Reduce Mass-rearing Costs and Increase Mating Success in Selected Fruit Pests in Support of SIT Application: microbiology. The full contents of the supplement are available online at https://bmcmicrobiol. biomedcentral.com/articles/supplements/volume-19-supplement-1.

\section{Authors' contributions}

Conceived and designed the study: KB, GT. Conducted the experiments and analyzed the results: $E A, M K, C B, R H, A H, C N, V D, G T$. Drafted the manuscript: EA, GT. All authors reviewed the manuscript. All authors read and approved the final manuscript.

\section{Funding}

This study was: (a) partially supported by the International Atomic Energy research contact no. 17074 as part of the Coordinated Research Project "Use of Symbiotic Bacteria to Reduce Mass-Rearing Costs and Increase Mating Success in Selected Fruit Pests in Support of SIT Application" and by intramural funds of the University of Patras to George Tsiamis, (b) partially supported by National Natural Science Foundation of China (31661143045) to Changying Niu and (c) partially supported by the International Atomic Energy research contact no. 17090 and 17011 as part of the Coordinated Research Project "Use of Symbiotic Bacteria to Reduce Mass-Rearing Costs and Increase Mating Success in Selected Fruit Pests in Support of SIT Application" to Ramesh Hire and Mahfuza Khan respectively.

\section{Availability of data and materials}

The datasets used and/or analyzed during the current study are available in $\mathrm{NCBI}$.

Ethics approval and consent to participate

Not applicable.

\section{Consent for publication}

Not applicable.

\section{Competing interests}

The authors declare that they have no competing interests.

\section{Author details}

${ }^{1}$ Department of Environmental Engineering, University of Patras, 2 Seferi St., 30100 Agrinio, Greece. ${ }^{2}$ Department of Fisheries \& Aquaculture Management, Technological Educational Institute of Western Greece, 30200 Messolonghi, Greece. ${ }^{3}$ Nuclear Agriculture \& Biotechnology Division, Bhabha Atomic Research Centre (BARC), Trombay, Mumbai, Maharashtra 400 085, India. ${ }^{4}$ Huazhong Agricultural University, Wuhan 430070, Hubei, China. ${ }^{5}$ Insect Biotechnology Division, Institute of Food and Radiation Biology (IFRB), Atomic Energy Research Establishment (AERE), Ganakbari, Savar, Dhaka 1349, Bangladesh. ${ }^{6}$ Insect Pest Control Laboratory, Joint FAO/IAEA Division of Nuclear Techniques in Food and Agriculture, Vienna International Centre, P.O. Box 100, 1400 Vienna, Austria.

Published: 24 December 2019

\section{References}

1. Duron O, Bouchon D, Boutin S, Bellamy L, Zhou L, Engelstädter J, et al. The diversity of reproductive parasites among arthropods: Wolbachia do not walk alone. BMC Biol. 2008;6:27.

2. Werren JH. Biology of Wolbachia. Annu Rev Entomol. 1997;42:587-609.

3. Werren JH, Baldo L, Clark ME. Wolbachia: master manipulators of invertebrate biology. Nat Rev Microbiol. 2008;6:741-51. 
4. O'Neill SL, Hoffmann A, Werren J. Influential passengers: inherited microorganisms and arthropod reproduction. New York: Oxford University Press; 1997.

5. Hilgenboecker $K$, Hammerstein $P$, Schlattmann $P$, Telschow A, Werren JH. How many species are infected with Wolbachia? - a statistical analysis of current data. FEMS Microbiol Lett. 2008;281:215-20.

6. Werren JH, Windsor D, Guo L. Distribution of Wolbachia among neotropical arthropods. Proc R Soc Lond B. 1995;262:197-204.

7. Werren $\mathrm{JH}$, Windsor DM. Wolbachia infection frequencies in insects: evidence of a global equilibrium? Proc R Soc B Biol Sci. 2000;267:1277-85.

8. Zug R, Hammerstein P. Still a host of hosts for Wolbachia: analysis of recent data suggests that $40 \%$ of terrestrial arthropod species are infected. PLoS One. 2012;7:e38544

9. de Oliveira CD, Gonçalves DS, Baton LA, Shimabukuro PHF, Carvalho FD, Moreira LA. Broader prevalence of Wolbachia in insects including potential human disease vectors. Bull Entomol Res. 2015;105:305-15.

10. Sazama EJ, Bosch MJ, Shouldis CS, Ouellette SP, Wesner JS. Incidence of Wolbachia in aquatic insects. Ecol Evol. 2017;7:1165-9.

11. Hughes GL, Allsopp PG, Brumbley SM, Woolfit M, McGraw EA, O’Neill SL. Variable infection frequency and high diversity of multiple strains of Wolbachia pipientis in Perkinsiella planthoppers. Appl Environ Microbiol. 2011;77:2165-8.

12. Sun X, Cui L, Li Z. Diversity and phylogeny of Wolbachia infecting Bactrocera dorsalis (Diptera: Tephritidae) populations from China. Environ Entomol. 2007;36:1283-9.

13. Beard CB, Durvasula RV, Richards FF. Bacterial symbiosis in arthropods and the control of disease transmission. Emerg Infect Dis. 1998:4:581-91.

14. Bourtzis K, O'Neill S. Wolbachia infections and arthropod reproduction: Wolbachia can cause cytoplasmic incompatibility, parthenogenesis, and feminization in many arthropods. BioScience. 1998;48:287-93.

15. Brucker RM, Bordenstein SR. Speciation by symbiosis. Trends Ecol Evol. 2012; 27:443-51

16. Charlat $\mathrm{S}$, Hurst GDD, Merçot $\mathrm{H}$. Evolutionary consequences of Wolbachia infections. Trends Genet. 2003;19:217-23.

17. Kageyama D, Narita S, Watanabe M. Insect sex determination manipulated by their endosymbionts: incidences, mechanisms and implications. Insects. 2012;3:161-99

18. Harris HL, Brennan LJ, Keddie BA, Braig HR. Bacterial symbionts in insects: balancing life and death. Symbiosis. 2010;51:37-53.

19. Hurst GDD, Jiggins FM, von der Schulenburg JHG, Bertrand D, West SA, Goriacheva II, et al. Male-killing Wolbachia in two species of insect. Proc R Soc B Biol Sci. 1999;266:735.

20. Stouthamer R, Breeuwer JA, GDD H. Wolbachia pipientis: microbial manipulator of arthropod reproduction. Annu Rev Microbiol. 1999;53: 71-102.

21. Cordaux R, Bouchon D, Grève P. The impact of endosymbionts on the evolution of host sex-determination mechanisms. Trends Genet. 2011;27: 332-41

22. Bourtzis K, Miller T. Insect symbiosis. USA: CRC Press, Taylor and Francis Group, LLC, Florida; 2003.

23. Gotoh T, Noda H, Ito S. Cardinium symbionts cause cytoplasmic incompatibility in spider mites. Heredity. 2007;98:13-20.

24. Weeks AR, Marec F, Breeuwer JAJ. A mite species that consists entirely of haploid females. Science. 2001;292:2479-82.

25. Zchori-Fein E, Perlman SJ, Kelly SE, Katzir N, Hunter MS. Characterization of a 'Bacteroidetes' symbiont in Encarsia wasps (Hymenoptera: Aphelinidae): proposal of 'Candidatus Cardinium hertigii.'. Int J Syst Evol Microbiol. 2004;54: 961-8.

26. Kenyon SG, Hunter MS. Manipulation of oviposition choice of the parasitoid wasp, Encarsia pergandiella, by the endosymbiotic bacterium Cardinium. J Evol Biol. 2007:20:707-16.

27. Xie R-R, Zhou L-L, Zhao Z-J, Hong X-Y. Male age influences the strength of Cardinium-induced cytoplasmic incompatibility expression in the carmine spider mite Tetranychus cinnabarinus. Appl Entomol Zool. 2010;45:417-23

28. Martin OY, Puniamoorthy N, Gubler A, Wimmer C, Germann C, Bernasconi MV, et al. Infections with the microbe Cardinium in the Dolichopodidae and other Empidoidea. J Insect Sci. 2013;13:47.

29. Zhao D-X, Zhang X-F, Hong X-Y. Host-symbiont interactions in spider mite Tetranychus truncates doubly infected with Wolbachia and Cardinium. Environ Entomol. 2013;42:445-52.
30. Gherna RL, Werren JH, Weisburg W, Cote R, Woeste CR, Mandelco L, et al. Arsenophonus nasoniae gen. nov., sp. nov., the causative agent of the sonkiller trait in the parasitic wasp Nasonia vitripennis. Int J Syst Bacteriol. 1991; 41:563-5.

31. Montenegro H, Solferini V. N., Klaczko L. B., Hurst G. D. D. male-killing Spiroplasma naturally infecting Drosophila melanogaster. Insect Mol Biol. 2005;14:281-7.

32. Tinsley MC, Majerus MEN. A new male-killing parasitism: Spiroplasma bacteria infect the ladybird beetle Anisosticta novemdecimpunctata (Coleoptera: Coccinellidae). Parasitology. 2006;132:757-65.

33. Zchori-Fein E, Perlman JS. Distribution of the bacterial symbiont Cardinium in arthropods. Mol Ecol. 2004;13:2009-16.

34. Weinert LA, Araujo-Jnr EV, Ahmed MZ, Welch JJ. The incidence of bacterial endosymbionts in terrestrial arthropods. Proc R Soc B Biol Sci. 2015;282: 20150249.

35. Zhang $Y-K$, Chen $Y-T$, Yang $K$, Hong $X-Y$. A review of prevalence and phylogeny of the bacterial symbiont Cardinium in mites (subclass: Acari). Syst Appl Acarol. 2016;21:978-90.

36. Nakamura Y, Kawai S, Yukuhiro F, Ito S, Gotoh T, Kisimoto R, et al. Prevalence of Cardinium bacteria in planthoppers and spider mites and taxonomic revision of "Candidatus Cardinium hertigii" based on detection of a new Cardinium group from biting midges. Appl Env Microbiol. 2009;75:6757-63.

37. Gruwell ME, Wu J, Normark BB. Diversity and phylogeny of Cardinium (Bacteroidetes) in armored scale insects (Hemiptera: Diaspididae). Ann Entomol Soc Am. 2009;102:1050-61.

38. Watts T, Haselkorn TS, Moran NA, Markow TA. Variable incidence of Spiroplasma infections in natural populations of Drosophila species. PLoS One. 2009:4:e5703.

39. Wilkes T, Duron O, Darby AC, Hypsa V, Novakova E, Hurst GDD. The genus Arsenophonus. In: Bourtzis K, Zchori-Fein E, editors. Manipulative tenants. USA: CRC Press, Taylor and Francis Group, LLC, Florida; 2011. p. 225-44.

40. Wang $L$, Jiang J, Xu Y, Zeng $L$, Lu Y. Occurrence of three intracellular symbionts (Wolbachia, Arsenophonus, Cardinium) among ants in southern China. J Asia Pac Entomol. 2016;19:981-8.

41. Jousselin E, d'Acier AC, Vanlerberghe-Masutti F, Duron O. Evolution and diversity of Arsenophonus endosymbionts in aphids. Mol Ecol. 2013;22:260-70.

42. Skinner SW. A third extrachromosomal factor affecting the sex ratio in the parasitoid wasp, Nasonia (=Mormoniella) vitripennis. Genetics. 1985; 109:745-59.

43. Drew R. Biogeography and speciation in the Dacini (Diptera: Tephritidae: Dacinae). Bish Mus Bull Entomol. 2004;12:165-78.

44. Drew R. The tropical fruit flies (Diptera: Tephritidae: Dacinae) of the Australasian and Oceanian regions. Mem Qld Mus. 1989;26:521.

45. Krosch MN, Schutze MK, Armstrong KF, Graham GC, Yeates DK, Clarke AR. A molecular phylogeny for the tribe Dacini (Diptera: Tephritidae): systematic and biogeographic implications. Mol Phylogenet Evol. 2012;64:513-23.

46. Virgilio M, Jordaens K, Verwimp C, White IM, De Meyer M. Higher phylogeny of frugivorous flies (Diptera, Tephritidae, Dacini): localised partition conflicts and a novel generic classification. Mol Phylogenet Evol. 2015;85:171-9.

47. Cugala DR, Meyer MD, Canhanga L. Integrated management of fruit flies case studies from Mozambique. In: Fruit fly research and development in Africa - towards a sustainable management strategy to improve horticulture. Cham: Springer; 2016. p. 531-52.

48. Dhillon MK, Singh R, Naresh JS, Sharma HC. The melon fruit fly, Bactrocera cucurbitae: a review of its biology and management. J Insect Sci. 2005;5:40.

49. Jessup AJ, Dominiak B, Woods B, Lima CPFD, Tomkins A, Smallridge CJ. Area-wide management of fruit flies in Australia. In: Area-wide control of insect pests. Dordrecht: Springer; 2007. p. 685-97.

50. Vargas RI, Piñero JC, Leblanc L, Manoukis NC, Mau RFL. Area-wide management of fruit flies (Diptera: Tephritidae) in Hawaii. In: Fruit fly research and development in Africa - towards a sustainable management strategy to improve horticulture. Cham: Springer; 2016. p. 673-93.

51. Alam U, Medlock J, Brelsfoard C, Pais R, Lohs C, Balmand S, et al. Wolbachia symbiont infections induce strong cytoplasmic incompatibility in the tsetse fly Glossina morsitans. PLoS Pathog. 2011;7:e1002415.

52. Bourtzis K. Wolbachia based technologies for insect pest population control. In: Transgenesis and the Management of Vector-Borne Disease. New York: Springer; 2008. p. 104-13.

53. Dobson SL, Fox CW, Jiggins FM. The effect of Wolbachia-induced cytoplasmic incompatibility on host population size in natural and manipulated systems. Proc R Soc Lond B Biol Sci. 2002;269:437-45. 
54. Dutra HLC, Rocha MN, Dias FBS, Mansur SB, Caragata EP, Moreira LA. Wolbachia blocks currently circulating zika virus isolates in Brazilian Aedes aegypti mosquitoes. Cell Host Microbe. 2016;19:771-4.

55. McMeniman CJ, Lane RV, Cass BN, Fong AWC, Sidhu M, Wang Y-F, et al. Stable introduction of a life-shortening Wolbachia infection into the mosquito Aedes aegypti. Science. 2009:323:141-4.

56. Moreira LA, Iturbe-Ormaetxe I, Jeffery JA, Lu G, Pyke AT, Hedges LM, et al. A Wolbachia symbiont in Aedes aegypti limits infection with dengue, Chikungunya, and Plasmodium. Cell. 2009;139:1268-78.

57. Saldaña MA, Hegde S, Hughes GL. Microbial control of arthropod-borne disease. Mem Inst Oswaldo Cruz. 2017;112:81-93.

58. Zabalou S, Riegler M, Theodorakopoulou M, Stauffer C, Savakis C, Bourtzis K. Wolbachia-induced cytoplasmic incompatibility as a means for insect pest population control. Proc Natl Acad Sci. 2004;101:15042-5.

59. Zhang D, Lees RS, Xi Z, Bourtzis K, Gilles JRL. Combining the sterile insect technique with the incompatible insect technique: III-robust mating competitiveness of irradiated triple Wolbachia-infected Aedes albopictus males under semi-field conditions. PLoS One. 2016;11:e0151864

60. Zhang D, Zheng X, Xi Z, Bourtzis K, Gilles JRL. Combining the sterile insect technique with the incompatible insect technique: I-impact of Wolbachia infection on the fitness of triple- and double-infected strains of Aedes albopictus. PLoS One. 2015;10:e0121126.

61. Zhang D, Lees RS, Xi Z, Gilles JRL, Bourtzis K. Combining the sterile insect technique with Wolbachia-based approaches: II- a safer approach to Aedes albopictus population suppression programmes, designed to minimize the consequences of inadvertent female release. PLoS One. 2015;10:e0135194.

62. Bourtzis K, Robinson AS. Insect pest control using Wolbachia and/or radiation. In: Bourtzis K, Miller T, editors. Insect symbiosis 2. Florida: CRC Press, Taylor and Francis Group, LLC; 2006. p. 225-46.

63. Zabalou S, Apostolaki A, Livadaras I, Franz G, Robinson AS, Savakis C, et al. Incompatible insect technique: incompatible males from a Ceratitis capitata genetic sexing strain. Entomol Exp Appl. 2009;132:232-40.

64. Apostolaki A, Livadaras I, Saridaki A, Chrysargyris A, Savakis C, Bourtzis K. Transinfection of the olive fruit fly Bactrocera oleae with Wolbachia: towards a symbiont-based population control strategy. J Appl Entomol. 2011:135:546-53.

65. Atyame CM, Cattel J, Lebon C, Flores O, Dehecq J-S, Weill M, et al. Wolbachia-based population control strategy targeting Culex quinquefasciatus mosquitoes proves efficient under semi-field conditions. PLoS One. 2015;10:e0119288.

66. Augustinos AA, Santos-Garcia D, Dionyssopoulou E, Moreira M, Papapanagiotou A, Scarvelakis M, et al. Detection and characterization of Wolbachia infections in natural populations of aphids: is the hidden diversity fully unraveled? PLoS One. 2011;6:e28695.

67. Bing X-L, Xia W-Q, Gui J-D, Yan G-H, Wang X-W, Liu S-S. Diversity and evolution of the Wolbachia endosymbionts of Bemisia (Hemiptera: Aleyrodidae) whiteflies. Ecol Evol. 2014;4:2714-37.

68. Gerth M. Classification of Wolbachia (Alphaproteobacteria, Rickettsiales): no evidence for a distinct supergroup in cave spiders. Infect Genet Evol. 2016; 43:378-80

69. Glowska E, Dragun-Damian A, Dabert M, Gerth M. New Wolbachia supergroups detected in quill mites (Acari: Syringophilidae). Infect Genet Evol. 2015:30:140-6.

70. Ros VID, Fleming VM, Feil EJ, Breeuwer JAJ. How diverse is the genus Wolbachia? Multiple-gene sequencing reveals a putatively new Wolbachia supergroup recovered from spider mites (Acari: Tetranychidae). Appl Environ Microbiol. 2009;75:1036-43.

71. Wang G-H, Jia L-Y, Xiao J-H, Huang D-W. Discovery of a new Wolbachia supergroup in cave spider species and the lateral transfer of phage WO among distant hosts. Infect Genet Evol. 2016;41:1-7.

72. Casiraghi M, Bordenstein SR, Baldo L, Lo N, Beninati T, Wernegreen JJ, et al. Phylogeny of Wolbachia pipientis based on gltA, groEL and ftsZ gene sequences: clustering of arthropod and nematode symbionts in the $F$ supergroup, and evidence for further diversity in the Wolbachia tree. Microbiology. 2005;151:4015-22.

73. O'Neill SL, Giordano R, Colbert AM, Karr TL, Robertson HM. 16S rRNA phylogenetic analysis of the bacterial endosymbionts associated with cytoplasmic incompatibility in insects. Proc Natl Acad Sci U S A. 1992;89: 2699-702.

74. Baldo L, Dunning Hotopp JC, Jolley KA, Bordenstein SR, Biber SA, Choudhury RR, et al. Multilocus sequence typing system for the endosymbiont Wolbachia pipientis. Appl Environ Microbiol. 2006;72: 7098-110.

75. Doudoumis V, Blow F, Saridaki A, Augustinos A, Dyer NA, Goodhead I, et al. Challenging the Wigglesworthia, Sodalis, Wolbachia symbiosis dogma in tsetse flies: Spiroplasma is present in both laboratory and natural populations. Sci Rep. 2017:7:4699.

76. Gasparich GE, Whitcomb RF, Dodge D, French FE, Glass J, Williamson DL. The genus Spiroplasma and its non-helical descendants: phylogenetic classification, correlation with phenotype and roots of the Mycoplasma mycoides clade. Int J Syst Evol Microbiol. 2004;54:893-918.

77. Heres A, Lightner DV. Phylogenetic analysis of the pathogenic bacteria Spiroplasma penaei based on multilocus sequence analysis. J Invertebr Pathol. 2010:103:30-5.

78. Hubert J, Kopecký J, Perotti MA, Nesvorná M, Braig HR, Ságová-Marečková $M$, et al. Detection and identification of species-specific Bacteria associated with Synanthropic mites. Microb Ecol. 2012;63:919-28.

79. Famah Sourassou N, Hanna R, Breeuwer JAJ, Negloh K, de Moraes GJ, Sabelis MW. The endosymbionts Wolbachia and Cardinium and their effects in three populations of the predatory mite Neoseiulus paspalivorus. Exp Appl Acarol. 2014;64:207-21

80. Mee PT, Weeks AR, Walker PJ, Hoffmann AA, Duchemin J-B. Detection of low-level Cardinium and Wolbachia infections in Culicoides. Appl Environ Microbiol. 2015;81:6177-88.

81. Hotopp JCD, Clark ME, Oliveira DCSG, Foster JM, Fischer P, Torres MCM, et al. Widespread lateral gene transfer from intracellular bacteria to multicellular eukaryotes. Science. 2007;317:1753-6.

82. Dunning Hotopp JC. Horizontal gene transfer between bacteria and animals. Trends Genet. 2011:27:157-63.

83. Kondo N, Nikoh N, ljichi N, Shimada M, Fukatsu T. Genome fragment of Wolbachia endosymbiont transferred to X chromosome of host insect. Proc Natl Acad Sci U S A. 2002;99:14280-5.

84. Nikoh N, Tanaka K, Shibata F, Kondo N, Hizume M, Shimada M, et al. Wolbachia genome integrated in an insect chromosome: evolution and fate of laterally transferred endosymbiont genes. Genome Res. 2008;18: 272-80

85. Aikawa T, Anbutsu H, Nikoh N, Kikuchi T, Shibata F, Fukatsu T. Longicorn beetle that vectors pinewood nematode carries many Wolbachia genes on an autosome. Proc R Soc B Biol Sci. 2009:276:3791-8.

86. Doudoumis V, Tsiamis G, Wamwiri F, Brelsfoard C, Alam U, Aksoy E, et al. Detection and characterization of Wolbachia infections in laboratory and natural populations of different species of tsetse flies (genus Glossina). BMC Microbiol. 2012;12:\$3.

87. Fenn K, Conlon C, Jones M, Quail MA, Holroyd NE, Parkhill J, et al. Phylogenetic relationships of the Wolbachia of nematodes and arthropods. PLoS Pathog. 2006;2:e94.

88. Husnik F, McCutcheon JP. Functional horizontal gene transfer from bacteria to eukaryotes. Nat Rev Microbiol. 2018;16:67-79.

89. Nikoh N, Nakabachi A. Aphids acquired symbiotic genes via lateral gene transfer. BMC Biol. 2009:7:12

90. Brelsfoard C, Tsiamis G, Falchetto M, Gomulski LM, Telleria E, Alam U, et al. Presence of extensive Wolbachia symbiont insertions discovered in the genome of its host Glossina morsitans morsitans. PLoS Negl Trop Dis. 2014:8:e2728.

91. Leclercq S, Thézé J, Chebbi MA, Giraud I, Moumen B, Ernenwein L, et al. Birth of a W sex chromosome by horizontal transfer of Wolbachia bacterial symbiont genome. Proc Natl Acad Sci U S A. 2016;113:15036-41.

92. Klasson L, Kambris Z, Cook PE, Walker T, Sinkins SP. Horizontal gene transfer between Wolbachia and the mosquito Aedes aegypti. BMC Genomics. 2009;10:33.

93. Woolfit M, Iturbe-Ormaetxe I, McGraw EA, O'Neill SL. An ancient horizontal gene transfer between mosquito and the endosymbiotic bacterium Wolbachia pipientis. Mol Biol Evol. 2009:26:367-74.

94. Kittayaponga P, Milnea JR, Tigvattananontb S, Baimaia V. Distribution of the reproduction-modifying bacteria, Wolbachia, in natural populations of tephritid fruit flies in Thailand; 2000

95. Augustinos AA, Drosopoulou E, Gariou-Papalexiou A, Asimakis ED, Cáceres C, Tsiamis $\mathrm{G}$, et al. Cytogenetic and symbiont analysis of five members of the $B$. dorsalis complex (Diptera, Tephritidae): no evidence of chromosomal or symbiont-based speciation events. ZooKeys. 2015;540:273-98.

96. Morrow JL, Frommer M, Royer JE, Shearman DCA, Riegler M. Wolbachia pseudogenes and low prevalence infections in tropical but not temperate 
Australian tephritid fruit flies: manifestations of lateral gene transfer and endosymbiont spillover? BMC Evol Biol. 2015;15:202.

97. Yong H-S, Song S-L, Chua K-O, Lim P-E. Predominance of Wolbachia endosymbiont in the microbiota across life stages of Bactrocera latifrons (Insecta: Tephritidae). Meta Gene. 2017;14:6-11.

98. Ventura IM, Martins AB, Lyra ML, Andrade CAC, Carvalho KA, Klaczko LB. Spiroplasma in Drosophila melanogaster populations: prevalence, malekilling, molecular identification, and no association with Wolbachia. Microb Ecol. 2012;64:794-801.

99. Karatepe B, Aksoy S, Karatepe M. Investigation of Wolbachia spp . and Spiroplasma spp. in Phlebotomus species by molecular methods. Sci Rep. 2018:8:10616.

100. Morag N, Klement E, Saroya Y, Lensky I, Gottlieb Y. Prevalence of the symbiont Cardinium in Culicoides (Diptera: Ceratopogonidae) vector species is associated with land surface temperature. FASEB J. 2012;26: 4025-34.

101. Jamnongluk W, Kittayapong P, Baimai V, O'Neill SL. Wolbachia infections of tephritid fruit flies: molecular evidence for five distinct strains in a single host species. Curr Microbiol. 2002;45:255-60.

102. Werren JH, Zhang W, Guo LR. Evolution and phylogeny of Wolbachia: reproductive parasites of arthropods. Proc R Soc Lond B. 1995;261:55-63.

103. Baldo L, Ayoub NA, Hayashi CY, Russell JA, Stahlhut JK, Werren JH. Insight into the routes of Wolbachia invasion: high levels of horizontal transfer in the spider genus Agelenopsis revealed by Wolbachia strain and mitochondrial DNA diversity. Mol Ecol. 2008;17:557-69.

104. Raychoudhury R, Baldo L, Oliveira DCSG, Werren JH. Modes of acquisition of Wolbachia: horizontal transfer, hybrid introgression, and codivergence in the Nasonia species complex. Evol Int J Org Evol. 2009;63:165-83.

105. Salunke BK, Salunkhe RC, Dhotre DP, Khandagale AB, Walujkar SA, Kirwale GS, et al. Diversity of Wolbachia in Odontotermes spp. (Termitidae) and Coptotermes heimi (Rhinotermitidae) using the multigene approach. FEMS Microbiol Lett. 2010;307:55-64.

106. Baldo L, Werren JH. Revisiting Wolbachia supergroup typing based on WSP: spurious lineages and discordance with MLST. Curr Microbiol. 2007;55:81-7.

107. Bell-Sakyi L, Palomar AM, Kazimirova M. Isolation and propagation of a Spiroplasma sp. from Slovakian Ixodes ricinus ticks in Ixodes spp. cell lines. Ticks Tick-Borne Dis. 2015;6:601-6.

108. Hornok S, Meli ML, Perreten A, Farkas R, Willi B, Beugnet F, et al. Molecular investigation of hard ticks (Acari: Ixodidae) and fleas (Siphonaptera: Pulicidae) as potential vectors of rickettsial and mycoplasmal agents. Vet Microbiol. 2010;140:98-104.

109. Subramanian G, Sekeyova Z, Raoult D, Mediannikov O. Multiple tickassociated bacteria in Ixodes ricinus from Slovakia. Ticks Tick-Borne Dis. 2012; 3:406-10.

110. Hanner R, Fugate M. Branchiopod phylogenetic reconstruction from 125 rDNA sequence data. J Crustac Biol. 1997;17:174-83.

111. Simon C, Frati F, Beckenbach A, Crespi B, Liu H, Flook P. Evolution, weighting, and phylogenetic utility of mitochondrial gene sequences and a compilation of conserved polymerase chain reaction primers. Ann Entomol Soc Am. 1994:87:651-701.

112. Woodman ME. Direct PCR of Intact Bacteria (Colony PCR). Curr Protoc Microbiol. 2008;9:A.3D.1-6.

113. Ntougias S, Polkowska Ż, Nikolaki S, Dionyssopoulou E, Stathopoulou P, Doudoumis $\mathrm{V}$, et al. Bacterial community structures in freshwater polar environments of Svalbard. Microbes Environ. 2016;31:401-9.

114. Edgar RC. MUSCLE: multiple sequence alignment with high accuracy and high throughput. Nucleic Acids Res. 2004;32:1792-7.

115. Kearse M, Moir R, Wilson A, Stones-Havas S, Cheung M, Sturrock S, et al. Geneious basic: an integrated and extendable desktop software platform for the organization and analysis of sequence data. Bioinformatics. 2012;28: 1647-9.

116. R Core Team. R: a language and environment for statistical computing. Vienna, Austria: R Foundation for statistical Computing; 2013. http://www.Rproject.org/.

117. Ronquist F, Huelsenbeck JP. MrBayes 3: Bayesian phylogenetic inference under mixed models. Bioinformatics. 2003:19:1572-4.

\section{Publisher's Note}

Springer Nature remains neutral with regard to jurisdictional claims in published maps and institutional affiliations.

\section{Ready to submit your research? Choose BMC and benefit from:}

- fast, convenient online submission

- thorough peer review by experienced researchers in your field

- rapid publication on acceptance

- support for research data, including large and complex data types

- gold Open Access which fosters wider collaboration and increased citations

- maximum visibility for your research: over $100 \mathrm{M}$ website views per year

At $\mathrm{BMC}$, research is always in progress.

Learn more biomedcentral.com/submissions 